\title{
XVI. Yüzyılda İstanbul'daki Halveti Tekkelerinde Mekânsal İşleyiş: Tekkelerin Mensup Oldukları Külliye İçindeki Diğer Birimlerle İlişsileri ${ }^{1}$
}

\begin{abstract}
Ayşe BÖLÜKBAŞI ${ }^{2}$
$\ddot{O} \mathbf{z}$

XVI. yüzyılda Osmanlı toplumsal hayatında en etkili tarikatlarından biri Halvetilikti. Halvetiler sahip oldukları bu gücü devlet idarecilerinin desteğine borçluydu. Bu sayede payitaht İstanbul başta olmak üzere birçok şehirde yaygın bir tekke ağına sahip olmuşlardı. Halveti tekkeleri çoğunlukla devlet adamları tarafindan inşa edilmiş irili ufaklı külliyelerin içerisindeydi. Söz konusu tekkeler mensup oldukları külliyelerin diğer birimleriyle irtibat ve etkileşim halindeydi. Cami, mescid, darülhadis, medrese, imaret, hamam gibi yapılarla tekkeler arasında gerek mekân, gerekse personel açısından ortaklıklar mevcuttu. Tekke mensupları kimi zaman külliyenin diğer birimlerinde görev alabiliyor; zikir, tevhid, sema gibi tasavvufi ritüelleri icra ederken diğer birimlere ait mekânları kullanabiliyor; kimi zamanda diğer birimlerin çeşitli imkânlarından faydalanabiliyordu. Bütün bunlar Halvetiliğe mensup kişilerin geniş toplumsal kesimlerle irtibat kurmasını sağladığı gibi, tarikatın etkisini azami seviyeye çıkarıyordu. Bu durum başlangıçtan itibaren tekke banilerinin arzu ettiği ve bilinçli olarak alt yapısını hazırladı $\breve{1}$ bir sürecin neticesiydi.
\end{abstract}

Anahtar Kelimeler: tekke, Halvetiyye, tevhidhane, darülhadis

Spatial Functioning in Khalwati Convents in the XVI. Century of Istanbul: Relations of Tekke Units to Other Structures in the Complex

\begin{abstract}
In the XVI. century, Khalvatiyya was one of the most influential orders in Ottoman social life. The order of Khalwatiyya owed this power to the support of government officials. In this respect, they had a widespread convent network in many cities, especially in Istanbul. Khalwati convents were mostly in the large or small complexes built by the statesmen. These convents were in contact and interaction with other units of the complexes they belonged to. There were partnerships in terms of space and staff between the convents and the mosque, masjid, madrasah, darülhadis, imaret, hamam of the complex. The members of a convent sometimes can get a job in other units of the complex; can use the spaces belonging to other units while they were performing the mystical rituals like zikir, tawhid, sema ; and sometimes they were able to benefit from the various facilities of other units. All this helped to keep members of Khalwatiyya in touch with the broader social sectors, as well as maximizing the influence of the order. From the beginning, it was the result of a process in which the patrons of these convents wanted and consciously prepared their sub-structure.
\end{abstract}

Keywords: convent, Khalwatiyya, tevhidhane, darülhadis

${ }^{1} \mathrm{Bu}$ makale Ayşe Bölükbaşı'ya ait (XVI. Yüzyılda Ístanbul'daki Halveti Tekkeleri, İstanbul Teknik Üniversitesi, Fen Bilimleri Enstitüsü, Basılmamış Doktora Tezi, dan. Prof. Dr. İlknur Kolay, İstanbul 2015) künyeli tezin IV. bölümünün I. kısmı; V. bölümünün II. ve III. kısmı ve I. kısmının bazı başlıkları esas alınarak hazırlanmıştır.

${ }^{2}$ Dr. Öğr. Üyesi, Bilecik Şeyh Edebali Üniversitesi, Güzel Sanatlar ve Tasarım Fakültesi, ayse.bolukbasi@bilecik.edu.tr Bu makale URKUND programı yardımıyla intihale karşı kontrol edilmiştir. 
Sultan II. Bayezid devrinde İstanbul'a nüfuz etmeye başlayan Halvetilik, XVI. yüzy1lda payitahtın en etkili tarikatlarından biri haline gelmiştir. Devlet idarecileri başta olmak üzere çeşitli toplumsal kesimlerle güçlü ilişkiler kuran Halvetiler, İstanbul'un sosyal ve kültürel hayatında belirleyici olan unsurlardan biriydi. $\mathrm{Bu}$ çalışmada temel olarak Halveti tekkelerinin mensup oldukları külliyelerin diğer birimleriyle ilişkileri ele alınacaktır. Bu girişim tekkelerdeki mekansal işleyişin anlaşılmasına yardımcı olacağı gibi tekkelerin toplumsal, ekonomik, politik ve kültürel etkisinin daha iyi anlaşılmasına da katkı sağlayacaktır.

XVI. yüzyıldaki Halveti tekkeleri mescit/cami-tevhidhane ya da müstakil bir tevhidhane, derviş hücreleri, selamlık, şeyhin ikamet ettiği hane ya da hücre, türbe, hazire, matbah, taamhane, kiler, hamam gibi bölümlerden tamamını veya bir kısmını ihtiva etmekteydi. Bu birimlerin boyutları, sayısı ve çeşidi tekkenin büyüklüğüne ve türüne göre değişmekteydi. XVI. yüzyılda İstanbul'da mevcut olan Halveti tekkeleri mekansal açıdan cami yanında bulunan tekkeler, mescit yanında bulunan tekkeler ve münzevi tekkeler olarak üç ana gruba ayrılabilir. En küçük grubu oluşturan münzevi tekkeler genel- likle şeyhler tarafindan inşa ettirilmişti. Banilerin mali imkanları sınırlı olduğu için söz konusu tekkeler mütevazı binalard $1^{1}$.

Diğer iki gruba mensup tekkeler ise (mescit veya cami yanındaki tekkeler) Halveti tekkelerinin büyük bir bölümünü oluşturuyordu. Bunlara komşu olan cami ya da mescid tarikat mensuplarınca tevhidhane ${ }^{2}$ olarak kullanmaktaydı. Namaz vakitleriyle çakışmamak üzere, zikir ve tevhitlerini burada gerçekleştirmekteydiler. Söz konusu tekkeler cami/mescid dışındaki başka binalarla da ilişki içindeydi. Bunlar duruma göre medrese, darülhadis, saray, hamam, imaret gibi yapılar olabiliyordu. Bunlardan bir kısmı doğrudan tekke mensuplarına hizmet vermeyen birimlerdi. Ancak tekke ünitesini oluşturan bölümlerden bir kısmı, darülhadis hücrelerinde, sarayın bahçesinde, medrese avlusunda vs. konumlandırılmıştı. Ortak mekânları kullanıp iç içe hizmet veriyorlardı. Hatta bazen tekke ile mensup olduğu külliyedeki diğer bir yapının personeli arasında kesişme olabiliyordu. Darülhadis-tekke yapılarında tekke şeyhi hem tekkede, hem darülhadiste görev yapabilmekte, cami-tekke yapılarında ise tekke şeyhi aynı zamanda cami vaizi olarak görevlendirilebilmekteydi.

\footnotetext{
${ }^{1}$ XVI. yüzyılda İstanbul'daki Halveti tekkelerinin banileri için bakınız: Ayşe Bölükbaşı, "Halveti Tekkelerinin İnşasında Devlet İdarecilerinin Rolü" History Studies (Prof. Dr. Şerafettin Turan'a Armağan), cilt 6, sayı 3, s. 71 87, Nisan 2014.

${ }^{2}$ Tevhidhane eğitim ve ibadet yapılan, dervişlerin sohbet, zikir, tevhid ve halvet ettikleri tekke birimidir. Bektaşilikte meydan, meydan evi; Mevlevilikte semahane diye adlandırılan bölümün diğer tarikatlarda tevhidhane olarak adlandırıldığı bilinmektedir (M. Baha Tanman, İstanbul Tekkelerinin Mimari ve Süsleme Özellikleri, Tipoloji Denemeleri, İstanbul Üniversitesi, Sosyal Bilimler Enstitüsü Basılmamış Doktora Tezi, İstanbul 1990, s.504).
} 


\section{Tekke Cami/Mescit Kesişmesi}

Halveti tekkelerinde tarikat erbabının ibadet ettiği, şeyhin müritlerini irşad ettiği, dervişlerin sohbet, zikir, tevhid ve halvet ettikleri yer tevhidhane olarak adlandırılırd. Ancak bu adlandırma arşiv belgelerinde kullanılmamaktadir. Belgelerde tevhid ve zikir yapılan yer "tekye" ${ }^{3}$, "hangah"4, zaviye ve mescid $^{5}$ olarak geçmektedir. Belgelerde cami/mescit ile zaviye/hangah/tekke yapıları çok iç içe anlatılmıştır. Hangah/zaviye/tekkede tevhid ve zikir gibi ibadetler yapılsın denilirken kastedilenin cami harimi mi, yoksa müstakil bir tevhidhane mi olduğu çoğu defa anlaşılmamaktadır. Ancak belgeler ve literatür birlikte değerlendirildiğinde XVI. yüzyılda İstanbul'daki Halveti tekkelerinde genellikle cami ya da mescidin tevidhane olarak kullanıldığı fikrine ulaşılmaktadır. ${ }^{6}$

Sadece Balat'taki Ferruh Kethüda Tekkesi'ne ait vakfiyede, tevhidhane yapısını anımsatan "cemiyethane" adıyla hususi bir birimden bahsedilmektedir. Bu yapının dervişlerin tevhid ve zikir yapmaları için uygun olup olmadığı bilinmemektedir ancak en azından burada sohbet ettikleri, birtakım ibadet ve irşad faaliyetleri için toplandıkları söylenebilir. Vakfiyede "cemiyethâne" kısmı zaviyenin bir birimi anlatılmakta ve zaviye şöyle tarif edilmektedir; "bir fevkani cemiyethâneli ve sofalı ve cemiyethâne altında bir kiları ve kilar yanında bir matbahı ve

\footnotetext{
3 Perizad Hatun Vakfiyesi, VGMA. D (Vakıflar Genel Müdürlüğü Arşivi Defterleri), nr. 570, s. 213219; Vakfiyenin Türkçesi; VGMA. D, nr. 2220, s. 175-183

${ }^{4}$ Hüsrev Kethüda Vakfiyesi, VGMA. D, nr. 1592, s. 1-40

${ }^{5}$ Atik Ali Paşa Vakfiyesi, Süleymaniye, Esad Efendi, nr. 3673, vr. 18b-23a.
}

kütüphanelik ile maruf bir hücreyi müştemil bir zaviye-i latife". ${ }^{7}$

Cami ya da mescidin tevhidhane olarak kullanıldığı yapılarda tevhidhaneler doğal olarak tekkenin en çok ziyaret edilen birimleriydi. XVI. yüzyılda Halveti şeyhlerinin tevhidhane olarak kullanılan cami ya da mescitte sadece devran ve zikir gibi tasavvufi ritüelleri gerçekleştirmedikleri, aynı zamanda vaizlik yaptıkları da bilinmektedir. Bunlardan birçoğu devrin en meşhur vaizleriydi. Bu durum toplumsal etkilerini iyice arttırıyordu. Tekkelere ait vakfiyelerde şeyhin vaizlik vazifesi özellikle vurgulanıyordu. Mesela Nurbanu Sultan vakfiyesinde tekke şeyhinin görevleri anlatılırken külliye içerisindeki camide mübarek gün ve gecelerde vaaz etmesi, nasihatleriyle cami cemaatini aydınlatması hususunun altı özellikle çizilmiştir. ${ }^{8}$

XVI. yüzyıl başlarında vaiz olarak görev yapan şeyhler Sünbül Efendi, Merkez Efendi, Cemaleddin İshak Karamani gibi birkaç kişiydi. Ancak daha sonra vaizlik yapan şeyh sayısında kayda değer bir artış yaşandı: Tercüman Yunus Tekkesi şeyhlerinden Yekçeşm Ahmed Efendi Eyüp'teki Nişancı Celal-zâde Camisi ile Galata'daki Arab Camisinde; Atik Valide Sultan tekkesi şeyhi Vişnezâde Mehmed

\footnotetext{
${ }^{6}$ Bu konuda ayrıntılı değerlendirmeler için bakınız: M. Baha Tanman, agt.

${ }^{7}$ Ferruh Kethüda Vakfiyesi, VGMA. D, nr. 570, s. 57-60; Vakfiyenin Türkçesi, VGMA. D, nr. 2111, s. 140-148.

${ }^{8}$ Nurbanu Sultan Vakfiyesi, VGMA.D, nr. 2113, s. 281-309; Vakfiyenin Türkçesi, VGMA. D, nr. 1766 , s. $136-170$.
} 
Efendi tekkesinin bulunduğu külliyedeki camide ${ }^{9}$; Şeyh Hızır İlyas Efendi ise önce Yeniçeri odalarındaki orta mescitte, ardından Habeşi Mehmed Ağa'nın yaptırdığı külliyedeki camide vaizlik yapmıştır ${ }^{10}$. Hızır İlyas Efendi aynı külliyenin içindeki tekkenin de meşihatını üstlenmişti. ${ }^{11}$ Önce Küçük Ayasofya Tekkesi'nde, ardından Sokullu Mehmet Paşa külliyesindeki tekkede şeyh olan Nureddinzâde, bir diğer Halveti şeyhi olan İbrahim Kırımi Efendi ve Koruklu Tekkesi şeyhi Tırhalalı Şeyh Ali Efendi ise selatin camilerinde vaizlik görevini üstlenmişlerdi. $^{12}$

Kimi Halveti meşayihi ile ulema arasında anlaşmazlıklar yaşanmışsa da, Halveti tarikatı mensupları ile ilmiye mensuplarının ilişkileri genel olarak iyiydi. Bu durum Halveti şeyhlerinin vaizlik gibi mühim görevleri üstlenmesini kolaylaştırmıştı. İstanbul'un en mühim külliyelerindeki tekkelerin meşihatını üstlenen Halveti şeyhlerinin aynı zamanda bu külliyelerdeki camilerde vaiz de olmaları daha geniş kitlelere ulaşmalarını sağlamıştır.

Tekke şeyhlerinin camilerde vaiz olarak görevlendirilmiş olması önemli bir noktaya da işaret etmektedir: Cami-tekkelerde cami alanı aynı zamanda tevhidhane olarak kullanılmakta, bu durumun yol açtığı mekansal bir kesişme, şeyhin camide vaiz olmasıyla cami-tekke personeli arasında da bir kesişmeye de yol açmaktadır.

\footnotetext{
${ }^{9}$ Nev'izade Atâi, Hadaiku'l- Hakaik fi Tekmileti'lŞakaik, nşr.Abdülkadir Özcan, İstanbul 1989, s. 361.

${ }^{10}$ Nev'izade Atâi, Hadaiku'l Hakayik, s.464-465.

${ }^{11}$ Mecdî Mehmet Efendi, Hadaiku'ş-Şakaik, nşr. Abdülkadir Özcan, İstanbul 1989, s. 517-518.
}

\section{Tekke-Darülhadis Kesişmesi}

Tekkelerin yer aldığı mütevazı ya da büyük külliyelerde darülhadisler de yer alabiliyordu. Daha dikkat çekici bir durum ise literatürde tekke diye bilinen bir yapının belgede darülhadis olarak anılması, darülhadis olarak bina edilen bir yapının tekkeye çevrilmesi yahut başlangıçta tekke olan bir yapının darülhadise dönüştürülmesiydi. Üsküdar'daki Şemsi Paşa Tekkesi, Davutpaşa'daki Şah Sultan Tekkesi, Eyüp'teki Cafer Ağa Tekkesi ve Çarşamba'daki Mehmed Ağa Tekkesi tekke-darülhadis kesişmesinin yaşandığı tekkelerdendir. Burada asıl dikkat çekilmek istenen husus ise darülhadislerin bazen tekke olarak da faaliyet göstermiş olmasıdır. Bu çerçevede darülhadisler ve tekkeler arasında işlevsel bazı ortaklıklar mevcut olabiliyor, tekke ve darülhadis mensupları aynı kişilerden oluşabiliyordu.

Literatürde Şemsi Ahmed Paşa'nın Üsküdar'daki külliyesinde yer alan tekkeden bahsedilmesine rağmen, külliyeye ait vakfiyede tekkeden bahsedilmemektedir. Vakfiyede on iki hücreli bir darülhadisten söz edilmektedir. Bu darülhadis muhtemelen tekke olarak kullanılmaktaydı. ${ }^{13}$ Ayrıca Şemsi Paşa Tekkesi'nin şeyhi ile darülhadisin muhaddisi aynı kişiydi. Halvetiyye şeyhlerinden Yayabaşızade Hızır İlyas, Üsküdar'daki Şemsi Paşa külliyesindeki darülhadiste müderris, zaviyede şeyh idi. ${ }^{14}$ Öte yandan, Şemsi Paşa'nın

\footnotetext{
${ }^{12}$ Nev'izade Atâi, Hadaiku'l Hakayik, s. 370, 471.

${ }^{13}$ Şemsi Paşa Vakfiyesi, VGMA.D, nr. 1489; nr. 456, s. 105-122

${ }^{14}$ Atâi, Hadaiku'l Hakayik, s. 464-465; Cahid Baltac1, XV ve XVI. Astrlarda Osmanlı Medreseleri, İstanbul 1976, s. 591.
} 
türbesinin, cami haremine açılmasından ötürü tekke mimarisini anımsattı̆̆ da söylenebilir. Tüm bu hususlar dikkate alındığında Şemsi Paşa tekkesiyle darülhadisinin aynı yapı olması ihtimali güçlenmektedir. ${ }^{15}$

Davutpaşa Şah Sultan Tekkesi'nde de benzer bir durum söz konusudur. Tekkeyi yaptıran banisi Yavuz Sultan Selim'in kızı Şah Sul$\tan$ XVI. yüzyılda yaşayan Halvetî tekkesi banileri arasında ayrıcalıklı bir yere sahiptir. Şah Sultan'ın Bahariye civarındaki sarayının bahçesinde bir Halveti tekkesi inşa ettirdiği ve Merkez Efendi Tekkesi'nin ikinci banisi olarak tekkeyi ihya ettiği de bilinmektedir. ${ }^{16}$ Literatürdeki bilgilere göre Şah Sultan Lütfi Paşa'yla evlendikten sonra eşinin vali olarak görevlendirildiği Yanya'ya yerleşmişti. Yanya'da Halvetî/Sünbüli şeyhi Yakub Efendi ile yakın temaslarda bulunmuş, büyük olasılıkla da O'nun müritleri arasına girmişti. Daha sonra eşi Lütfi Paşa veziriazam olduktan sonra Şah Sultan Davutpaşa mahallesinde bir camii ve bir tekke bina ettirip, buranın meşihatını üstlenmesi için Yakub Efendi'yi İstanbul'a davet etmiştir. Yakub Efendi Davutpaşa tekkesinin şeyhiyken, Merkez Efendi Koca Mustafa Paşa tekkesinin meşihatını üstlenmiştir. Merkez Efendi'nin ölümü

${ }^{15}$ Gülru Necipoğlu ise Sinan'ın eserlerinin anlatıldığı Tuhfet'ül Mimarin adlı eserde Şemsi Paşa Tekkesi'nden bahsedilmesine rağmen, vakfiyede tekkeden bahsedilmediğini belirtmektedir. Muhyiddin Efendi'nin Tomar-1 Tekayası'nda bu tekkenin adının İsfendiyar Tekkesi diye geçmesinden dolayı, bu tekkenin İsfandiyar ailesinin ortaklaşa yaptırdığı bir aile yapısı olabileceğini ifade etmektedir (Gülru Necipoğlu, The Age of Sinan-Architectural Culture in The Ottoman Empire, London 2005, s.425, 549). üzerine Yakub Efendi Koca Mustafa Paşa Tekkesi'nin meşihatına geçmiştir. Yakub Efendi'nin Şah Sultan'ın tekkesinden ayrılışı, Şah Sultan'1 çok üzmüş, bu üzüntünün etkisiyle Davutpaşa tekkesini medreseye çevirmeyi tercih etmiştir. ${ }^{17}$

Vakfiyede ise literatürde tekke diye tanımlanan bu binanın bir darülhadis olarak inşa edildiği ancak orada yaşayan "süleha" sayısı azaldığ için medreseye çevrildiği anlatılmaktadır: "İstanbul'da Davutpaşa kurbünde olan cami-i şerife bitişik bir bina inşa edip darülhadis olsun deyu şart buyurdukları hücrelerde hizmet eden şeyh'ül hadis ve orada iskân eden sülehadan çok azı kaldığından devrin sultanının reyi ile buranın medreseye..." çevrildiği ifade edilmektedir.

Darülhadis-tekkenin medreseye çevrilmesinde Şah Sultan'ın - şeyhinin başka bir tekkeye geçişinden dolayı - bu yöndeki isteği ya da burada meskun sülehanın sayısının (derviş/talebe) azalması etkili olmuş olabilir. Ancak burada dikkat çekilmesi gereken asıl husus yapının vakfiyede darülhadis olarak nitelenmesidir. Belki de başlangıçtan beri burası bir darülhadistekke niteliğinde bir kurumdu. Halveti tekkelerine ait birçok vakfiyede şeyhlerin tefsir ve ha-

\footnotetext{
${ }^{16}$ Şah Sultan Vakfiyesi'nin Osmanlı Türkçesi Tercümesi, EV.VKF (Başbakanlık Osmanlı Arşivi Vakfiyeler Tasnifi), 9/20; Vakfiyenin Türkçe Tercümesi, nr. 1993, s. 11-17. Ayrica bu konuda bkz. Necipoğlu, The Age of Sinan, s. 296; M. Baha Tanman, "Merkez Efendi Külliyesi", Türkiye Diyanet Vakfi Íslam Ansiklopedisi, Ankara 2004, XXIX, 202-205.

${ }^{17}$ Yusuf Sinaneddin b. Yakup, Menâkıb-ı Şerif-i ve Tarikat-nâme-yi Piran ve Meşayih-i Tarikat-l Aliyye-i Halvetiyye, İstanbul 1290, s. 62-64; Atâi, Hadaiku'l Hakayik, s. 204-207.
} 
dis ilimlerinde uzman kişiler arasından seçilmesi şart koşulduğu gibi, Şah Sultan vakfiyesinde de darülhadis medreseye dönüştürüldükten sonra dahi, müderrisin hadis ilmine önem vermesi hususu vurgulanmıştır. ${ }^{18}$

Eyüp'teki Cafer Ağa Tekkesi'nde ise darülhadis (medrese) ile tekke yapısı bir arada görünmektedir. Yapının bazı kaynaklarda "medrese"19 bazı kaynaklarda ise "darülhadis"20 diye geçmesi, burada da darülhadis-tekke kesişmesi ihtimalini güçlendirmektedir. Bugünkü türbe alanının tevhidhane olarak kullanılmış olabileceği söylenmekle ${ }^{21}$ birlikte, darülhadise (medrese) ait dershane yapısının tevhidhane olarak kullanılma ihtimali üzerinde de durulmuştur. ${ }^{22}$ Darülhadis avlusu ve hücreleri, tekke dervişleri ve darülhadis görevlileri tarafindan ortaklaşa kullanılmış olmalıdır.

Bu tekke, içinde Cafer Ağa'nın darülhadisini (medrese) ve türbesini barındıran mütevazı bir külliyenin içinde bulunmaktadır. Ayvansarayi Kızıl Mescit yakınında diye tanımladığı bu yapıyı şöyle tasvir etmektedir; "Klzıl Mescid ....ve karîbinde vâkî̀' türbede Cafer Paşa medfundur. Paşa-yı mumâ-ileyhin orada bir

\footnotetext{
${ }^{18}$ Şah Sultan Vakfiyesi'nin Osmanlı Türkçesi Tercümesi, EV.VKF, 9/20; Vakfiyenin Türkçe Tercümesi, nr. 1993, s. 11-17.

19 Ayvansarayi Hüseyin Efendi, Ali Sâtı Efendi, Süleyman Besin Efendi, Hadikat'ül Cevami/İstanbul Camileri ve Diğer Dini Sivil Mimari Yapılar, İstanbul 2001, s. 360; M. Baha Tanman, "Cafer Paşa Külliyesi", Dünden Bugüne İstanbul Ansiklopedisi, İstanbul 1994, II, 367-369; A. Bilgin Turnal1, "Cafer Paşa Tekkesi", Türkiye Diyanet Vakfi İslam Ansiklopedisi, İstanbul 1992, VI, 555.

${ }^{20}$ Cahid Baltac1, XV ve XVI. Astrlarda Osmanl Medreseleri,585-586.

${ }^{21}$ A. Bilgin Turnalı, Cafer Paşa Tekkesi, s. 555.

${ }^{22}$ M. Baha Tanman, Cafer Paşa Külliyesi,s. 367369.
}

medresesi ve târik-i Halvetiyye'ye meşrût olarak zaviyesi dahi vardır. Ta'allukâtıyla türbe-i mezburede medfunlardır. Hayrâtının cümlesi hâlâ harâbdır". ${ }^{23}$

Tekkenin tevhidhanesinin neresi olduğuyla ilgili farklı görüşler mevcuttur. Tekkenin Sadiyye tekkesine dönüştüğü dönemdeki şeyhi Mehmed Salih Sırrı Efendi'ye ait bir vakfiye hulasasında Cafer Paşa Türbesi'nden ve türbede bulunan bir hücreden bahsedilmesine dayanılarak, tevhidhanenin türbe bitişiğindeki bir odadan ibaret olduğu ileri sürülmüştür. ${ }^{24}$

$\mathrm{Bu}$ türbe-tevhidhane türündeki yapının caddeye bakan tarafında ilk inşa dönemine ait mihrap bulunması, tekkenin Saadiyye tarikatına bağlı olduğu dönemdeki şeyh mezarlarının yine bu kısımda bulunması, türbe ve tevhidhanenin aynı yap1 olabileceği hususunu desteklemektedir. Birçok tarikat yapısında şeyh ve dervişlerinin halka şeklinde sandukaların etrafinda devran gerçekleştirdikleri bilinmektedir. Nitekim XVI. yüzyılda İstanbul'u ziyaret eden seyyahlardan Gerlach da muhtemelen Ramazan Efendi Tekkesi'nde ${ }^{25}$ yapılan devranı şöyle anlatmak-

\footnotetext{
${ }^{23}$ Ayvansarayi Hüseyin Efendi, Hadikat'ül Cevami, s.360.

${ }^{24}$ A. Bilgin Turnal, Cafer Paşa Tekkesi, s.555

25 Gerlach, Samatya civarında Ermenilerin Aziz Georgius Kilisesi'nden hareketle bu kabre geldiklerini anlatmaktadır (Stephan Gerlach, Türkiye Günlüğ̈̈ 1573-1576, ed. Kemal Beydilli, İstanbul, 2006, s. 329.) Bugün sözkonusu kiliseden yürüme mesafesinde Ramazan Efendi Tekkesi, Bezzazistan Atik Kethüdası Hacı Hüsrev tarafindan evinin bahçesinde yaptırılmıştı. Dolayısıyla bahsedilen yerin bu yap1 olması muhtemeldir. Ayrıntılı bilgi için bakınız: Bölükbaşı, XVI. Yüzyılda İstanbul'daki Halveti Tekkeleri, s. 57-58.
} 
tadır: ".. Yolumuza devamla, içinde kutsal sayllan bir kişinin kabri bulunan bir Türk'ün evine geldik. Kabrin karşısında 5-6 kişi sıra halinde el ele tutuşmuşlar, arkalarında gene 5-6 kişi ve karşılarında da 5-6 kişi el ele tutuşarak dans ediyor, slçrlyorlar ve sürekli "Hu,hu" diye bağrıyorlardı".

Öte yandan darülhadis (medrese) dershanesinin tekke tevhidhanesi olarak kullanıldığı, hücrelerin bir kısmının tekke hücresi, bir kısmının darülhadis (medrese) hücresi şeklinde tasarlandığı yapıların da mevcut olduğu bilinmektedir. Buna dayanarak, Cafer Paşa Tekkesi'nde darülhadis (medrese) dershanesinin tevhidhane olarak kullanılmış olabileceği söylenebilir. Nitekim literatürdeki mevcut bilgiler de bunu desteklemektedir. ${ }^{26}$ Cafer Paşa'nın vakfiyesi bulunamadığından, darülhadis (medrese) dershanesinin mi yoksa türbenin bitişiğindeki bir odanın mı tevhidhane olarak kullanıldığ 1 tam açıklığa kavuşturulamamıştır. Ancak darülhadis hücrelerinin bir kısmı muhakkak derviş hücreleri olarak kullanılmış olmalıdır.

Bunlara ilaveten darülhadis yapısıyla tekke yapısının bütün birimlerinin ayrı olduğu ancak görevlilerin ortak olduğu durumlar da mevcuttur. Mehmed Ağa Tekkesi'nde darülhadis ve tekkenin külliye içinde farklı yerlerde bulunduğu ve caminin ortak kullanım alanı olması dışında, her iki yapının da birbirinden bağımsız

\footnotetext{
${ }^{26}$ M. Baha Tanman, Cafer Paşa Külliyesi, s.368

${ }^{27}$ Habeşi Mehmet Ağa Vakfiyesi, TSMK, Emanet Hazinesi, nr. 3028

${ }^{28}$ Soğukkuyu'daki Piri Mehmet Paşa Tekkesi ve Davutpaşa'daki Şah Sultan Tekkesi XVI. yüzyılda medreseye dönüştürülen tekkelerdendir. Sonraki yüzyıllarda Halveti Tekkeleri medreseye dönüştürülmeye devam edilmiştir. Cafer Ağa
}

olduğu düşünülmektedir. Yayabaşızâde Hızır İlyas, Şemsi Paşa Tekkesi'nden sonra Mehmet Ağa Tekkesi'nin şeyhliğini yürütürken, darülhadisinde ise muhaddis olarak görev yapmıştı2 ${ }^{27}$.

\section{Tekke-Medrese Kesişmesi}

Tekkeler ile medreseler arasındaki kesişmeyi Halveti tekkeleri üzerinden incelediğimizde iki husus karşımıza çıkmaktadır: İlki tekke iken medreseye dönüştürülen binalar meselesi, ikincisi ise tekke ve medrese mensuplarının aynı külliye içinde ortak kullanım alanlarına sahip olmaları meselesidir. XVI. yüzyılda İstanbul'daki Halveti tekkelerinden sadece birkaçının medreseye dönüştürüldüğü bilinmektedir. ${ }^{28}$ Ancak vakıf belgelerinde tekkelerin medreseye çevrilmemesi hususunda ikazların mevcudiyeti, tekkelerin medreseye dönüştürülmesi yönünde yükselen bir temayül olduğunu düşündürmektedir. Mesela Sokullu Mehmed Paşa Payas'ta yaptırdığı hangahın medreseye dönüştürülmemesini vakfiyesinde şart koşar. Ancak vakfiyede hangah diye bahsedilen tekke yapis1nın sonradan medreseye dönüştürüldüğü bilinmektedir. ${ }^{29}$ Anlaşılan tekke binaları kolaylıkla darülhadise dönüştürülebildiği gibi medreseye de çevrilebilmektedir. Ancak bir şeyhin bir medresede müderris olması, darülhadiste muhaddis olması kadar olağan bir şey olmasa gerek. Dolayısıyla bir tekkenin medreseye dönüş-

Medresesi, Koğacıdede Medresesi bunlardan birkaçıdır. Bu konuda geniş bilgi için bakınız: Bölükbaşı, XVI. Yüzyılda Istanbul'daki Halveti Tekkeleri, s. 148-150.

${ }^{29}$ Sokollu Mehmed Paşa Vakfiyesi, VGMA. D, nr. 572, s. 27-63; Vakfiyenin Türkçesi; VGMA. D, nr. 2104, s. 442-478. 
türülmesinden sonra şeyh ve dervişleri muhakkak kendilerine başka bir tekke bulmak durumunda kalmış olmalıdırlar.

Tekke ve medrese mensuplarının aynı külliye içinde ortak kullanım alanlarına sahip olmalarına en iyi örnek Piyale Paşa Tekkesidir. Piyale Paşa'nın elimizdeki iki vakfiyesinde de külliye içindeki tekkeden hatta medreseden de bahis yoktur. ${ }^{30}$ Ancak külliyeyle ilgi araştırma yapan uzmanlar külliyenin bir tekke ihtiva ettiği görüşünü ileri sürer. Piyale Paşa Külliyesi içindeki tekkeden Evliya Çelebi de bahsetmektedir. ${ }^{31}$ Ayvansarayi ise daha detaylı bir tanımlama yaparak medrese ve tekke hücrelerinin sayısını bile vermiştir; "Piyale Paşa Camii bânîsi kapudan paşalardan Vezir Piyale Paşa ibn-i Abdurrahman'dır. Ve pîşgâhında vâki havlısında bir sıra hücerât vardır. Bir tarafi medrese hücerâtı ve bir tarafı hânkâh halvethaneleridir. ...ve haric-i cami de dâhi yemin ve yesâr iki mahfil-i âli olup, her biri yigirmi beşer sütun

${ }^{30}$ Piyale Paşa'nın Vakfiyeleri, EV.VKF, 4/34;

VGMA. D, nr. 573, s. 111-115

${ }^{31}$ Evliya Çelebi tekkeden şöyle bahsetmektedir; "Hikmet i Hudâ bu câmii Piyâle Paşa merhûm binâya şürû etdükde câmiin şimâlî tarafinda yedi husrevânî küp altun bulduğu yer hâlâ zâhir ü bâhirdir kim hâlâ ol küpler İslâmbol'da Uzun Çârsû başındaki sebîlhânesi içinde durur mermer küplerdir. Böyle helâl mâl ile binâ olunmuş câmidir. Ve bir tekye ve kendilere bir medfen ve bir hammâm ve bir çârsû binâ etmişdir". Evliya Çelebi bin Derviş Muhammed Zilli, Evliya Çelebi Seyahatnamesi, İstanbul 1996, I, s.202-203.

${ }^{32}$ Ayvansarayi Hüseyin, Hadikat'ül Cevami, s.421. Ayrıca Necipoğlu 1573 tarihli ikinci vakfiyede Mevlana Derviş bin Abdullah-el imam ve Şeyh Mahmud el-hatib diye bahsedilen kimselerin de şahitlerin arasında gösterilmesini bu külliyenin içinde tekke olduğuna kanıt olarak göstermektedir. Necipoğlu, The Age of Sinan, s. 425,549. Hatta 1565 tarihli ilk vakfiyede de Derviş İbni Abdullah el- üzerinde bina olunmuştur. Ve mezbur sütûnlardan mâa'dâ kemer altında dahi on iki direk vardır ve tekke tarafinın kemerleri yirmi dokuz, medrese tarafinın kemerleri on sekiz ve abdest muslukları olan sakf iki direk üzere bina olunmuştur. Türbe haricinde dâ'iren mâa'dâ yigirmi iki adet direkler vardır”. ${ }^{32}$

Piyale Paşa Külliyesi'nin restitüsyonu oluşturulurken külliyenin içine tekke de yerleştirilmiştir. Külliyede medrese avlusu ile tekke avlusunun ortak olduğu düşünülmektedir. ${ }^{33}$ Medrese ve tekke personeli belli vakitlerde bu avluda karşılaşmış ve aynı mekânı kullanmış olmalıdırlar.

Piyale Paşa Tekkesi'nde olduğu üzere Koca Mustafa Paşa, Atik Ali Paşa, Sokullu Mehmet Paşa ve Atik Valide tekkelerinin içinde bulunduğu külliyelerde de medrese mevcuttur. Bu tekkelerde Piyale Paşa Tekkesi'nden farklı olarak, medrese ve tekke külliyenin içinde farklı yerlerde konumlandırılmış müstakil yapılardır.

imam adındaki şahitten bahsedilmektedir (Piyale Paşa Vakfiyesi, VGMA.D, nr. 573, s. 111-115). Kastamonu İl Halk Kütüphanesi'nde bulduğumuz Koruklu Tekkesi meşayihini anlatan bir menakıbnamede ise Piyale Paşa'nın camisine imam ve hatip olarak Cerrah Paşa Şeyhi diye tanınan İbrahim Efendi'nin tayin edildiği belirtilmektedir (Menâkıb-ı Meşayih-i Zaviye-i Koruklu, Arşiv no: 37 Hk 1012/21, vr. 341b). Piri Mehmed Paşa'nın inşâ ettirdiği Koruklu Tekkesi, Halvetî tekkesi olarak inşâ ettirilip, bu yıllarda aynı tarikata bağlı olduğundan, Piyale Paşa Tekkesi'nin de Halvetî tekkesi olduğunu düşünmek yerinde olacaktır.

33 Tanman külliyenin içinde tekke ve medresenin kesin olarak var olduğunu ancak iki vakfiyede de bahsedilmemiş olmasını, bu birimlerin 1573 'ten sonra paşanın vakfettiği gayrimenkullerin gelirleriyle inşa ettirilmesi ihtimaliyle açıklamaktadır: M. Baha Tanman, "Piyale Paşa Külliyesi'nin Yerleşim Düzeni ve Mimarisi" Piyale Paşa Camii 2005-2007 Restorasyonu, İstanbul 2011, s.101. 
Koca Mustafa Paşa, Atik Ali Paşa ve Piyale Paşa tekkelerinde cami harimi tevhidhane olarak kullanılırken ${ }^{34}$, Sokullu Mehmed Paşa ve Atik Valide külliyelerinde tekke yap1ları ayrı birer tevhidhaneye sahiptir. Ancak bu son iki tekkede de cami namaz vakitlerinde ortak buluşma noktasıydı. Dolayısıyla bahsedilen bu yapıların tümünde, tekke mensupları ile medrese mensupları belli vakitlerde buluşmaktaydilar.

Halveti tarikatı mensupları ehli sünnet akidesiyle ve bu akidenin en önemli savunucuları olan ulema ile iyi ilişkilere sahipti. Tarikatın bazı ritüellerine yönelik ulemanın eleştirileri ve bazı kolların farklı yaklaşımları istisnai olarak kabul edilirse, Halvetilik ulema ve devlet ricali arasında hüsnükabul görüyordu. Öte yandan Halveti şeyhlerinden Sinanüddin Yusuf ${ }^{35}$ Kurd Efendi ${ }^{36}$ ve Süleyman Ekmeleddin Tekkesi şeyhlerinden Şeyh Mustafa Beyani ${ }^{37}$ medrese eğitimi aldıktan sonra Halveti tarikatına intisap etmişlerdi. Hatta Halveti şeyhlerinden medresede tedrisat işiyle ilgilenenler bile bulunmaktadır. Mesela medrese kökenli Halveti şeyhlerinden Sarhoş Bali Efendi'nin, Halveti tekkesinde

\footnotetext{
${ }^{34}$ Piyale Paşa Camisi hariminin hem tevhidhane hem de dershane olarak kullanıldığı düşünülmektedir. Gerlach, Piyale Paşa Camisi'ni ziyaretinde caminin içinde ders yapan kişilerden bahseder; "..yüksek kubbenin altında birileri oturuyordu, bir kişi onlara ders veriyordu" (Gerlach, age, s. 187).

${ }^{35}$ Atâi, Hadaiku'l Hakayik, s.359-360.

${ }^{36}$ Atâi, Hadaiku'l Hakayik, s.363.

${ }^{37}$ Atâi, Hadaiku'l Hakayik, s.466-467.

${ }^{38}$ XVI. yüzyılda şeyhlerin medrese muhitinden gelen müridlerini, diğer dervişlerden farklı bir usulle eğitime tabi tutup, medrese ile tekkedeki vazifelerini birlikte yürütmelerine müsaade verdikleri ve bu şekilde ulemanın tasavvufa meylinin arttığ bilinmektedir. Halveti şeyhlerinden Sarhoş Bali Efendi (ö. H.
}

şeyh iken aynı zamanda medresede müderrislik yaptığı da bilinmektedir. ${ }^{38}$

Bu konuda önemli bir örnek de Mehmed Dâi isimli şeyh efendidir. Sultan III. Murad Han devrinde İstanbul'a davet edilmiş ve vakfına bir takım temlikler yapılmıştır. Kendisi Gelibolu'daki hanesini medreseye dönüştürmüş, vefatına kadar bu medresede ilim ve tedrisat ile meşgul olmuştur..$^{39}$

\section{Tekke-Saray İlişkisi}

Tekkelerin cami-mescit, darülhadis, medrese binalarıyla olduğu gibi banilerinin yaptırdığı saraylarla da yakın ilişkisi olabiliyordu. XVI. yüzyıldaki Halveti tekke banilerinden birkaçı tekkesini sarayının bahçesinde, bir kısmı ise sarayının çok yakınında inşa ettirmiştir. Bu durum tekke banilerinin sadece hayırsever baniler olmadığını, tarikatın doğrudan müntesibi olduğu kanaatini güçlendirmektedir. XVI. yüzyılda İstanbul'da Halveti tekkesi yaptıran banilerden Şah Sultan, Doğancı Ahmed Paşa ve Perizad Hatun tekkesini sarayının bahçesinde; Ferruh Kethüda ise sarayının karşı tarafına inşa ettirmiştir. Bunlara göre daha az varlıklı olan

980/M. 1572-1573) tasavvuf silkine medrese tahsilinden sonra girmiştir. Tahsilini tamamladıktan sonra Kanuni'nin hocası Hayreddin Efendi'ye mülazım (asistan) olmuş ve Kepenekçi Medresesi'nde ders vermeye başlamıştır. Daha sonra tasavvuf yoluna girmek istediğinde ise şeyhi Ramazan Efendi ona zikir telkin edip tarikat usul ve adabını öğretmiş, ama tedrisi tamamen bırakmasına da müsaade etmemiştir. Bali Efendi'nin tekkedeki halvethaneden ç1kıp medreseye gittiği, dersini verdikten sonra tekrar hücresine döndüğü rivayet edilmektedir (Atâi, $\mathrm{Ha}$ daiku'l Hakayik, s. 209-210; Reşat Öngören, Osmanlılarda Tasavvuf, Anadolu'da Sufiler Devlet ve Ulema (16. Yüzyıl), İz Yayıncılık, İstanbul 2000, s. 360).

${ }^{39}$ Atâi, Hadaiku'l Hakayik, s.600-601. 
Bezzazistan Atik Kethüdası Hacı Hüsrev ise tekkesini evinin bahçesinde yaptırmıştır.

Tekkeler ile baninin sarayının bazen çok iç içe olduğu görülmektedir. Mesela Doğancı Ahmet Paşa vakfiyesinde saray müştemilatı detaylı bir şekilde tarif edilirken türbedar odasından da bahsedilir. ${ }^{40}$ Türbedar odasının bu kadar yakın olması, tekkenin de saray bahçesinde olma ihtimalini akla getirmektedir. Bugün türbe ile cami aynı avluda bulunmaktadır. Doğancı Ahmed Paşa Türbesi'nin yanında bulunan, ilk banisinin Çakırcı Hasan Paşa olduğu düşünülen cami, tekke tevhidhanesi olarak kullanılmışsa, tekke de saraya türbe kadar yakın olmalıdır. ${ }^{41}$

Saray bahçesinde bulunan diğer bir tekke de Şah Sultan Tekkesi'dir. Şah Sultan'ın mülklerine bitişik olduğu söylenilen saray, cami-tekkeye çok yakındır. Hatta sarayın bahçesindedir. Şah Sultan'ın sarayı da vakfiyesinde detaylı bir şekilde anlatılmıştır. Şah Sultan'ın sarayı Doğancı Ahmed Paşa Sarayı'na göre daha mütevazı iç ve dış avlusu olan on odalı, iki matbahlı, bir hamamı, ahırı ve çeşmesi olan bir yapıdır. Hem saray, hem de şeyhe ve dervişlere tahsis edilen yapılar denize nazırdır. ${ }^{42}$
Literatürde tekkesinin sarayının bahçesinde olduğu söylenilen Perizad Hatun'un vakfiyesinde ise saraydan bahsedilmez. Bahsedilmemesinin sebebi bu sarayın, Perizad Hatun'un eşi Arap Ahmed Paşa tarafından yaptırılmış olmasından kaynaklanabilir. Ancak bu tekkenin de saray bahçesinde yapıldığı sonucuna literatürdeki bilgilerden yaralanarak ulaşmak mümkündür. Perizâd Hatun'un cami-tekkesinin sarayın bahçesinde olduğunu Ayvansarayi şöyle anlatmaktadır; "Câmi'in yeri Paşa-y1 mezburun bağçesi olub, zevcesine hibe eylemiştir. Vâkıfei mezbûre müteveffâ oldukdan vasiyyeti üzerine vâsisi el-Hac Mehmed Ağa, sülüs mâlından bir zâviye ve ittisâlinde bir mescit-i âli bina eylemiştir ve senevi üç yüz guruş vakfının îrâdı vardır. Vâkıfe-i mumâ-ileyhâ ile zevc-i müşarünileyha mescid-i mezbur kurbünde vâki' türbede medfundurlar. Mukâbilinde vâki' çeşme müşarünileyhin hayrıdır ki, târihi budur: $982 "{ }^{43}$

Ferruh Kethüda Cami-Tekkesi ise baninin sarayının bahçesinde değil karşısında yaptırılmıştır. Saraya çok yakın bir mesafededir. Ferruh Kethüda Vakfiyesi'nde saraydan detaylıca bahsedilmiştir. ${ }^{44}$ Ferruh Kethüda'nın sarayı, Doğancı Ahmet Paşa ya da Şah Sultan sarayına göre daha görkemli bir yapıdır ve denize bakan köşklere sahiptir.

Aydın Yüksel, Osmanlı Mimarisinde Kanuni Sultan Süleyman Devri: İstanbul (1520-1566), İstanbul Fetih Cemiyeti, İstanbul 2004, s.88).

${ }^{42}$ Şah Sultan Vakfiyesi'nin Osmanlı Türkçesi Tercümesi, EV.VKF, 9/20; Vakfiyenin Türkçe Tercümesi, nr. 1993, s. 11-17.

${ }^{43}$ Ayvansarayi Hüseyin, Hadikat'ül Cevami, s.479.

${ }^{44}$ Ferruh Kethüda Vakfiyesi, VGMA. D, nr. 570, s. 57-60; Vakfiyenin Türkçesi,VGMA. D, nr. 2111, s. $140-148$. 
Bezzazistan Atik Kethüdası Hacı Hüsrev ise Halveti şeyhi Ramazan Efendi için yaptırdığı tekkeyi evinin bahçesinde inşa ettirmiştir. Vakfiyede cami-tekkenin yeri şöyle tarif edilmektedir; "Koca Mustafa Paşa Camii kurbünde Yazıcı Bahçesi demekle maruf mülk menzilimde izn-i sultani ile bir cami-i şerif bina edüb...". Bu ifade Hüsrev Kethüda'nın camitekkeyi kendi mülkü olan bir arazi üzerinde yaptırdığı bilgisini de vermektedir. ${ }^{45}$

Doğancı Ahmed Paşa, Şah Sultan, Perizad Hatun ve Ferruh Kethüda tekkeleri dışında saray yanında olduğu söylenilen ancak vakfiyelerinde saraydan bahsedilmeyen yapılar vardır. $\mathrm{Bu}$ yapılarda tekkelerin sarayın bahçesinde olduğu söylenilemez. Ancak tekkenin içinde bulunduğu külliye aynı zamanda baninin sarayı yakınında inşa edilmiştir. Bunlar arasında Kadırga'da Sokullu Mehmed Paşa'nın ${ }^{46}$, Üsküdar'da Nurbanu Sultan'ın ve Davutpaşa'da Şah Sultan' $1 n^{47}$ tekkelerinin içinde bulunduğu külliyeler banilerin ya da eşlerinin yaptırdıkları sarayların yakınında bulunmaktadır.

Tekkenin baninin sarayının bahçesinde veya yakınında olması, tekke/tarikat ile bani

${ }^{45}$ Hüsrev Kethüda Vakfiyesi, VGMA.D, nr. 1592, s. 1-40; Necipoğlu, The Age of Sinan, s.504

${ }^{46}$ Tülay Artan, "In the Tracks of a Lost Palace", 9. Milletlerarası Türk Sanatları Kongresi (9th International Congress of Turkish Art), Istanbul, 1991, IX, 197-203; "The Kadırga Palace: An Architectural Reconstruction", Muqarnas ,Cambridge 1993, X, 201211.

${ }^{47}$ Necipoğlu, The Age of Sinan, s.288, 294

${ }^{48}$ M. Baha Tanman, "Kitchens of the Ottoman Tekkes as Reflections of Imarets in Sufi Architecture", Feeding People, Feeding Power-Imarets in the Ottoman Empire, N. Ergin, C. K. Neumann, A. Singer (eds.), Eren Press, İstanbul 2007, 211-239. arasındaki ilişkiye ayrı bir hususiyet kazandırmaktaydı. Bu durum banilerin inşa faaliyetinin sıradan bir girişim olmadığ katın bir güçlü bir müntesibi olduklarını akla getirmektedir.

\section{Tekke-İmaret ve Tekke-Hamam İlişkisi}

Halveti tekkeleri mensup oldukları külliyedeki darülhadis, medrese, mescit, saray gibi birimlerle mekân yahut personel açısından müşterek birtakım noktalara sahipti. Buna ek olarak tekke mensupları külliye içindeki bütün birimlerin ortaklaşa kullandıkları imaret ve hamam gibi mekânlardan da yararlanıyorlardı.

Tekke yaşantısında dervişlerin beslenme ihtiyaçlarının karşılanması önemli bir husustu. Ayrıca tekkeyle irtibatı olan, özellikle mübarek gün ve gecelerde tekkeye gelip giden kişilere ikramlarda bulunulması da gerekebiliyordu. Bu ihtiyaçlar tekkelerin kendi matbahları vasıtasıyla karşılanabildiği gibi, tekkeyle bağlantılı başka birimler kullanılarak da giderilebiliyordu. ${ }^{48}$ XVI. yüzyılda İstanbul'daki Halveti tekkelerinden birçoğu kendi matbahına sahipti. ${ }^{49} \mathrm{Bu}$ tür tekkeler cami-tekke, mescittekke veyahut sadece tekke olan mütevazı binalardı. Bazılarının ise kendine ait özel matbahları

\footnotetext{
49 Elimizde vakıf belgesi bulunan yirmi altı tekkeden on yedisi matbaha sahipti. Balat, Küçük Ayasofya, Merkez Efendi, Mimar Acem Ali, Ramazan Efendi, Eyüp'teki Şah Sultan, Yahya Kethüda, Soğukkuyu, Mehmed Ağa, Doğancı Ahmet Paşa camitekkeleri; Alaeddin Efendi, Süleyman Ekmeleddin, Koruk, Hacı Kadın ve Koğacı Dede mescit-tekkeleri; Sokullu Mehmed Paşa ve Sinan Erdebili tekkeleri matbaha sahip olan yapılardır. Bu konuda geniş bilgi için bakınız: Ayşe Bölükbaşı, " Osmanlı Tekkeleri'nde Beslenme XVI. Yüzyılda İstanbul'daki Halveti Tekkeleri Örneği", Vakanüvis- Uluslararası Tarih Araştırmaları Dergisi, vol.3, say1: 1 (Bahar, 2018), s.83-112.
} 
yoktu. Bunlar beslenme ihtiyacını bulundukları külliyelerin imaretini kullanarak gideriyordu. Tekke-imaret ilişkisinin yoğunlaşması bu tip tekkeler söz konusu olduğunda ortaya çıkıyordu. İmaretler tekke sakinleriyle külliyedeki diğer birimlere mensup kişilerin hepsinin ihtiyacını karşılayan mekânlardı. Bu nedenle tekkelerin kesiştikleri darülhadis, medrese, cami, saray gibi diğer yapılardan daha geniş bir etkileşime imkan sağlıyorlardı. Beslenme ihtiyacını mensup olduğu külliyenin imaretinden karşılayan tekkeler Atik Valide Tekkesi, Atik Ali Paşa Cami-Tekkesi ve Koca Mustafa Paşa CamiTekkesiydi. Bunların yararlandıkları imaretler küçük yapılar değildi. Mesela Atik Ali Paşa külliyesindeki imaret asıl birimlere ek olarak mahzen, ahır, kenef ve odunluğa sahipti.

$\mathrm{Bu}$ imaretlerden bazılarında tekke şeyhine ve dervişlerine ne kadar yemek verileceği vakfiyede belirtilmişken, diğer bir kısmında buna gerek duyulmamıştır. Atik Valide Tekkesi'nin içinde bulunduğu külliyenin imaretinde kime ne kadar yemek tahsis edildiği vakfiyede ayrıntılı bir şekilde anlatılmıştı. ${ }^{50}$ Ancak Koca Mustafa Paşa ve Atik Ali Paşa Tekkesi'nde tekke müritleri ve şeyhi için ne kadar yemek ayrılacağı belirtilmeksizin, bütün külliye için genel olarak ne kadar yiyecek temin edilip, yemek yapılacağı belirtilmiştir.

\footnotetext{
${ }^{50}$ Nurbanu Sultan Vakfiyesi, VGMA. D, nr. 2113, s. 281-309; Vakfiyenin Türkçesi, VGMA. D, nr. 1766, s. 136-170; Atik Ali Paşa Vakfiyesi, Süleymaniye, Esad Efendi, nr. 3673, vr. 18b - 23a; Ömer Lütfi Barkan, Ekrem Hakk1 Ayverdi, 953 (1546)Tarihli İstanbul Vakıfları Tahrir Defteri, İstanbul Enstitüsü, İstanbul 1970, s.369.
}

Matbah-tekke ilişkisine benzer bir durum hamam için de söz konusuydu. Sokullu Mehmet Paşa Tekkesi ve Sinan Erdebili Tekkesi'nde olduğu üzere sadece tekke görevlilerine tahsis edilen hamamlar olduğu gibi tekkenin içinde bulunduğu külliyenin hamamından faydalanan tekkeler de mevcuttu.

Sokullu Mehmet Paşa Tekkesi'nin zemin katında dervişlerin kullanımına sunulmuş tek halvetli hamam (gusülhane) bulunmaktaydı. ${ }^{51}$ Sinan Erdebili Tekkesi'nde ise hamam şeyh evinin bir birimi olarak görünmektedir; "menzil der mahalle-i Ayasofya beyt-i süfli ve iki gurfe ve hamam ve matbah ve bi'r mâ ve mahzen ve kenif...". 52

Hacı Kadın Tekkesi, Merkez Efendi Tekkesi, Mimar Acem Tekkesi, Atik Ali Paşa Tekkesi, Koca Mustafa Paşa, Küçük Ayasofya Tekkesi, Atik Valide Tekkesi, Mehmed Ağa Tekkesi gibi hamamın tekke-cami avlu duvarlarının dışında olduğu örnekler de mevcuttur. $\mathrm{Bu}$ hamamların tekke görevlilerinin ihtiyacını karş1ladığı gibi, tekkenin içinde bulunduğu külliyede varsa medrese, mektep, cami görevlilerine de mahalle halkına olduğu gibi hizmet sunduğu düşünülmelidir. Netice olarak hamamlar da imaretler gibi tekke sakinlerinin, külliyedeki diğer birimlerin görevlileriyle, mahalle sakinleriyle bir araya geldikleri, ortaklaşa kullandıkları mekânlardır ${ }^{53}$.

\footnotetext{
${ }^{51}$ M. Baha Tanman, "Sinan'ın Mimarisi Tekkeler", Mimarbaşı Koca Sinan, Yaşadı̆̆ Çağ ve Eserleri, İstanbul 1988, s.311-312

52 Sinan Erdebili Vakfiyesi, VGMA.D, nr. 571, s. 1; Mehmet Canatar, İstanbul Vakıflarl Tahrir Defteri 1009 (1600) Tarihli, İstanbul 2004, s. 3.

${ }^{53}$ Ayşe Bölükbaşı, XVI. Yüzyılda İstanbul'daki Halveti Tekkeleri, s. 144-145.
} 


\section{SONUÇ}

XVI. yüzyılda İstanbul'daki Halveti tekkelerinin birçoğu irili ufaklı külliyeler içinde inşa edilmişti. Bu yüzden tekke sakinleri, külliyede mevcut diğer birimlerin mensuplarıla yoğun bir etkileşim içindeydi. Bazen tekkenin ana birimleri dahil külliye içindeki pek çok birim ortaklaşa kullanılıyordu. Bu durum Halvetiliğin toplumsal etkisini ciddi miktarda arttırıyordu. Cami, medrese, kervansaray, imaret, hamam gibi külliye birimlerinin sayısı ve buralardan istifade eden kişilerin fazlalığı düşünüldüğünde bu durum doğal bir sonuçtu. Aslında bu durum devlet idarecilerinin Halvetiliğe verdiği desteğin amacına ulaştığı anlamına geliyordu. XVI. yüzyılda İstanbul'da inşa edilen Halveti tekkelerinin üçte ikisinden fazlası yönetici sınıfa mensup kişiler tarafından inşa ettirilmişti. Sağlanan bu desteğin temel sebebi Halvetiliğin temsil ettiği İslam anlayışının devlet idarecileri ve ilmiye sınıfı mensupları tarafından kabul görmesiydi. Halveti meşayihi ve ulema arasında bazı görüş ayrılıkları olmakla birlikte önemli bir anlaşmazlık söz konusu değildi. Bunun sonucunda İstanbul'daki Halveti tekke ağ toplumsal etkileşime uygun büyük külliyeler içinde konumland1. Bu durum tekke ile camii, medrese, darülhadis, imaret, hamam gibi yapılar arasında yakın ilişkilere yol açtı.

Bahsedilen mekânsal kesişmeler, tekke görevlilerinin başka yapılarda görevlendirilmesiyle ortaya çıkan personel kesişmesiyle de desteklenmişti. Özellikle tekke şeyhlerinin darülhadislerde muhaddis olması ile büyük camilerde vaiz olması personel kesişmesini apaçık bir şekilde ortaya koymaktadır. Özellikle vaiz olan şeyhler çok geniş kitleleri etkileyebilmiştir. Bütün bunlar Halveti şeyhlerini tekkelerinde münzevi bir yaşam süren mutasavviflar olmaktan çıkarmış, farklı toplum kesimlerinden kimselerle yakın temas içinde olan etkili kişilere dönüştürmüştür.

\section{Kaynakça \\ Vakfiyeler ve Arşiv Belgeleri}

Atik Ali Paşa Vakfiyesi, Süleymaniye, Esad Efendi, nr. 3673, vr. 18b-23a.

Doğancı Ahmed Paşa Vakfiyesi, VGMA.D (Vakıflar Genel Müdürlüğü Arşivi Defterleri), nr. 503, s. 327-336.

Ferruh Kethüda Vakfiyesi, VGMA. D, nr. 570, s. 57-60; Vakfiyenin Türkçesi,VGMA. D, nr. 2111, s. 140-148.

Habeşi Mehmet Ağa Vakfiyesi, TSMK, Emanet Hazinesi, nr. 3028.

Hüsrev Kethüda Vakfiyesi, VGMA. D, nr. 1592, s. $1-40$.

Nurbanu Sultan Vakfiyesi, VGMA.D, nr. 2113, s. 281-309; Vakfiyenin Türkçesi, VGMA. D, nr. 1766, s. $136-170$.

Perizad Hatun Vakfiyesi, VGMA. D, nr. 570, s. 213-219; Vakfiyenin Türkçesi; VGMA. D, nr. 2220, s. $175-183$.

Piyale Paşa'nın Vakfiyeleri, EV.VKF, 4/34; VGMA. D, nr. 573, s. 111-115.

Sinan Erdebili Vakfiyesi, VGMA.D, nr. 571, s. 1.

Sokollu Mehmed Paşa Vakfiyesi, VGMA. D, nr. 572, s. 27-63; Vakfiyenin Türkçesi; VGMA. D, nr. 2104, s. 442-478.

Şah Sultan Vakfiyesi'nin Osmanlı Türkçesi Tercümesi, EV.VKF (Başbakanlık Osmanlı Arşivi Vakfiyeler Tasnifi), 9/20; Vakfiyenin Türkçe Tercümesi nr. 1993, s. 11-17.

Şemsi Paşa Vakfiyesi, VGMA.D, nr. 1489; nr. 456, s. $105-122$.

\section{Makale ve Kitaplar}

Artan, Tülay, "In the Tracks of a Lost Palace", 9. Milletlerarast Türk Sanatlarl Kongresi (9th International Congress of Turkish Art), İstanbul, 1991, IX, 197-203.

Artan, Tülay, "The Kadırga Palace: An Architectural Reconstruction", Muqarnas ,Cambridge 1993, X, 201-211. 
Ayvansarayi Hüseyin Efendi, Ali Sâtı Efendi, Süleyman Besin Efendi, Hadikat'ül Cevami/İstanbul Camileri ve Diğer Dini Sivil Mimari Yapılar, İstanbul 2001.

Baltacı, Cahid, $X V$ ve XVI. Astrlarda Osmanl Medreseleri, İstanbul 1976.

Barkan, Ömer Lütfi; Ekrem Hakkı Ayverdi, 953 (1546)Tarihli Ístanbul Vakıflarl Tahrir Defteri, İstanbul Enstitüsü, İstanbul 1970.

Bölükbaşı, Ayşe, "Halveti Tekkelerinin İnşasında Devlet İdarecilerinin Rolü" History Studies (Prof. Dr. Şerafettin Turan'a Armağan), cilt 6, Nisan 2014, say1 3, s. 71-87.

Bölükbaşı, Ayşe, XVI. Yüzyılda İstanbul'daki Halveti Tekkeleri, İstanbul Teknik Üniversitesi, Fen Bilimleri Enstitüsü, Basılmamış Doktora Tezi, dan. Prof. Dr. İlknur Kolay, İstanbul 2015.

Bölükbaşı, Ayşe, "Osmanlı Tekkeleri'nde Beslenme XVI. Yüzy1lda İstanbul'daki Halveti Tekkeleri Örneği", Vakanüvis- Uluslararası Tarih Araştırmaları Dergisi, vol.3, sayı: 1 (Bahar, 2018), s.83-112.

Canatar, Mehmet, Istanbul Vakıflarl Tahrir Defteri 1009 (1600) Tarihli, İstanbul 2004.

Evliya Çelebi bin Derviș Muhammed Zilli, Evliya Çelebi Seyahatnamesi, İstanbul 1996, c. I.

Gerlach, Stephan, Türkiye Günlüğ̈̈ 1573-1576, ed. Kemal Beydilli, İstanbul 2006.

Mecdî Mehmet Efendi, Hadaiku'ş-Şakaik, nşr. Abdülkadir Özcan, İstanbul 1989.

Menâkıb-ı Meşayih-i Zaviye-i Koruklu, Arşiv no: 37 Hk 1012/21, vr. 341b.

Nev'izade Atâi, Hadaiku'l- Hakaik fi Tekmileti'lŞakaik, nşr.Abdülkadir Özcan, İstanbul 1989.

Necipoğlu, Gülru, The Age of Sinan-Architectural Culture in The Ottoman Empire, London 2005.

Öngören, Reşat, Osmanlılarda Tasavvuf, Anadolu'da Sufiler Devlet ve Ulema (16. Yüzyıl), İstanbul 2000 .

Tanman, M. Baha, İstanbul Tekkelerinin Mimari ve Süsleme Özellikleri,Tipoloji Denemeleri, İstanbul Üniversitesi, Sosyal Bilimler Enstitüsü Basılmamış Doktora Tezi, İstanbul 1990.

Tanman, M. Baha, "Piyale Paşa Külliyesi'nin Yerleşim Düzeni ve Mimarisi" Piyale Paşa Camii 2005 2007 Restorasyonu, İstanbul 2011.

Tanman, M. Baha, "Kitchens of the Ottoman Tekkes as Reflections of Imarets in Sufi Architecture", Feeding People, Feeding Power-Imarets in the Ottoman Empire, N. Ergin, C. K. Neumann, A. Singer (eds.), Eren Press, İstanbul 2007, s. 211-239.
Tanman, M. Baha, "Sinan'ın Mimarisi Tekkeler", Mimarbaşı Koca Sinan, Yaşadığı Çağ ve Eserleri, İstanbul 1988.

Tanman, M. Baha, "Cafer Paşa Külliyesi", Dünden Bugüne İstanbul Ansiklopedisi, İstanbul 1994, II, 367-369.

Tanman, M. Baha, "Merkez Efendi Külliyesi", Türkiye Diyanet Vakfi Íslam Ansiklopedisi, Ankara 2004, XXIX, 202-205.

Turnalı, A. Bilgin, "Cafer Paşa Tekkesi", Türkiye Diyanet Vakfi İslam Ansiklopedisi, İstanbul 1992, VI, 555

Yusuf Sinaneddin b. Yakup, Menâkıb-ı Şerif-i ve Tarikat-nâme-yi Piran ve Meşayih-i Tarikat-l Aliyye-i Halvetiyye, İstanbul 1290.

Yüksel, İ. Aydın, Osmanlı Mimarisinde Kanuni Sultan Süleyman Devri: İstanbul (1520-1566), İstanbul Fetih Cemiyeti, İstanbul 2004. 
EK-1: 16. Yüzyıl İstanbul'undaki Halveti Tekkeleri

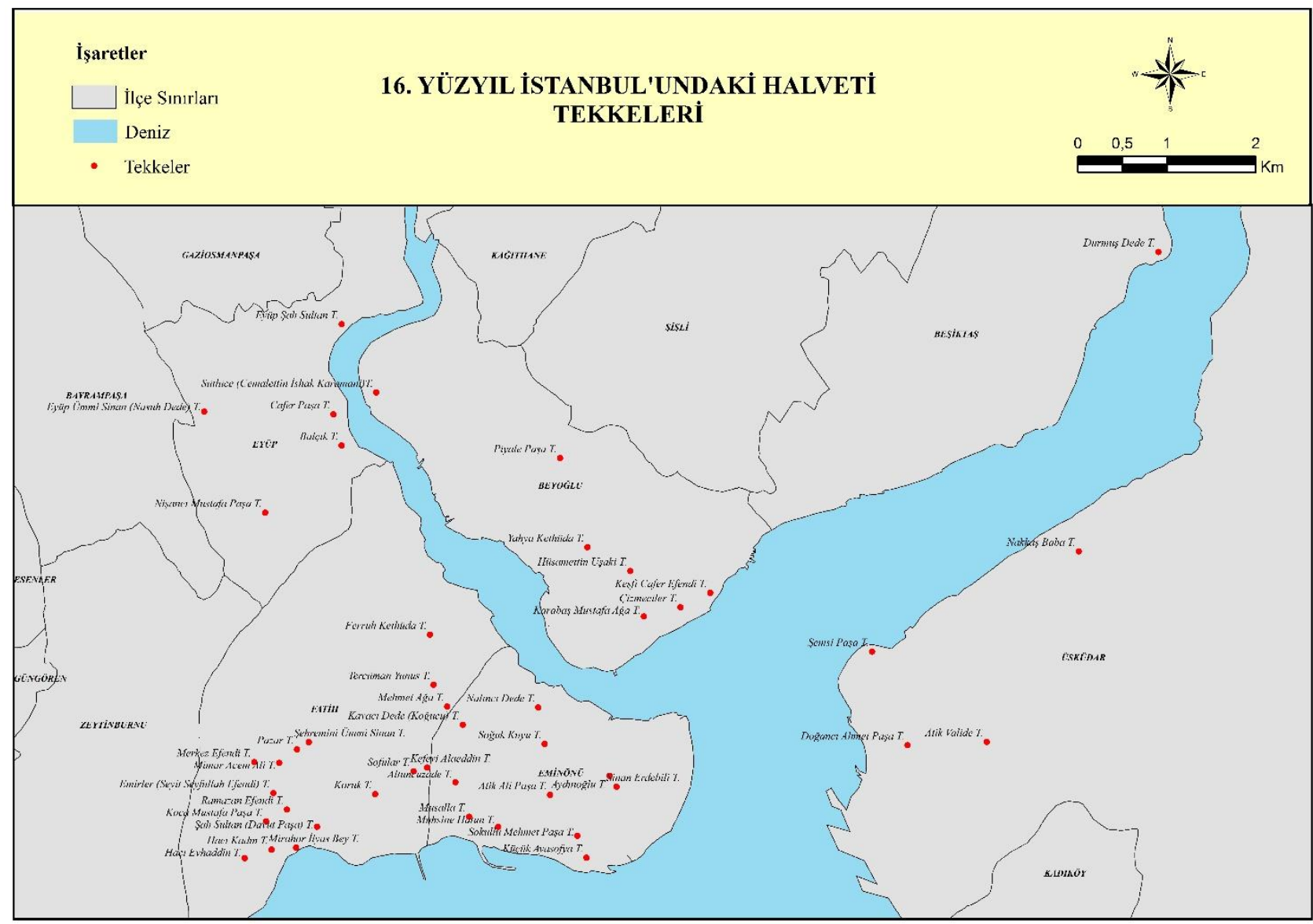

Kaynak: Ayşe Bölükbaşı, XVI. Yüzyılda İstanbul'daki Halveti Tekkeleri, Ek-B, s.4 
EK-2: Ferruh Kethüda (Balat) Tekkesi

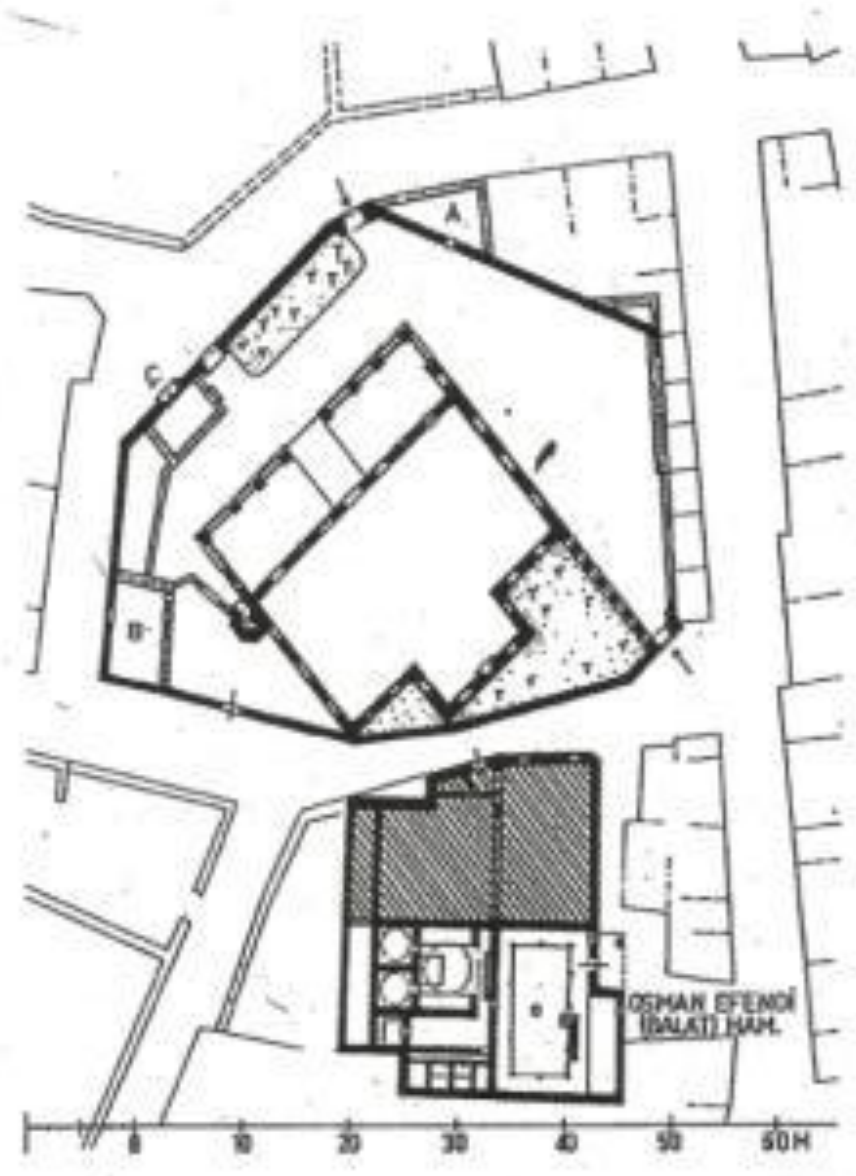

Kaynak: Wolfgang Müller Wiener, İstanbul'un Tarihsel Topografyası, İstanbul, 2001 
EK-3: Ferruh Kethüda (Balat) Tekkesi

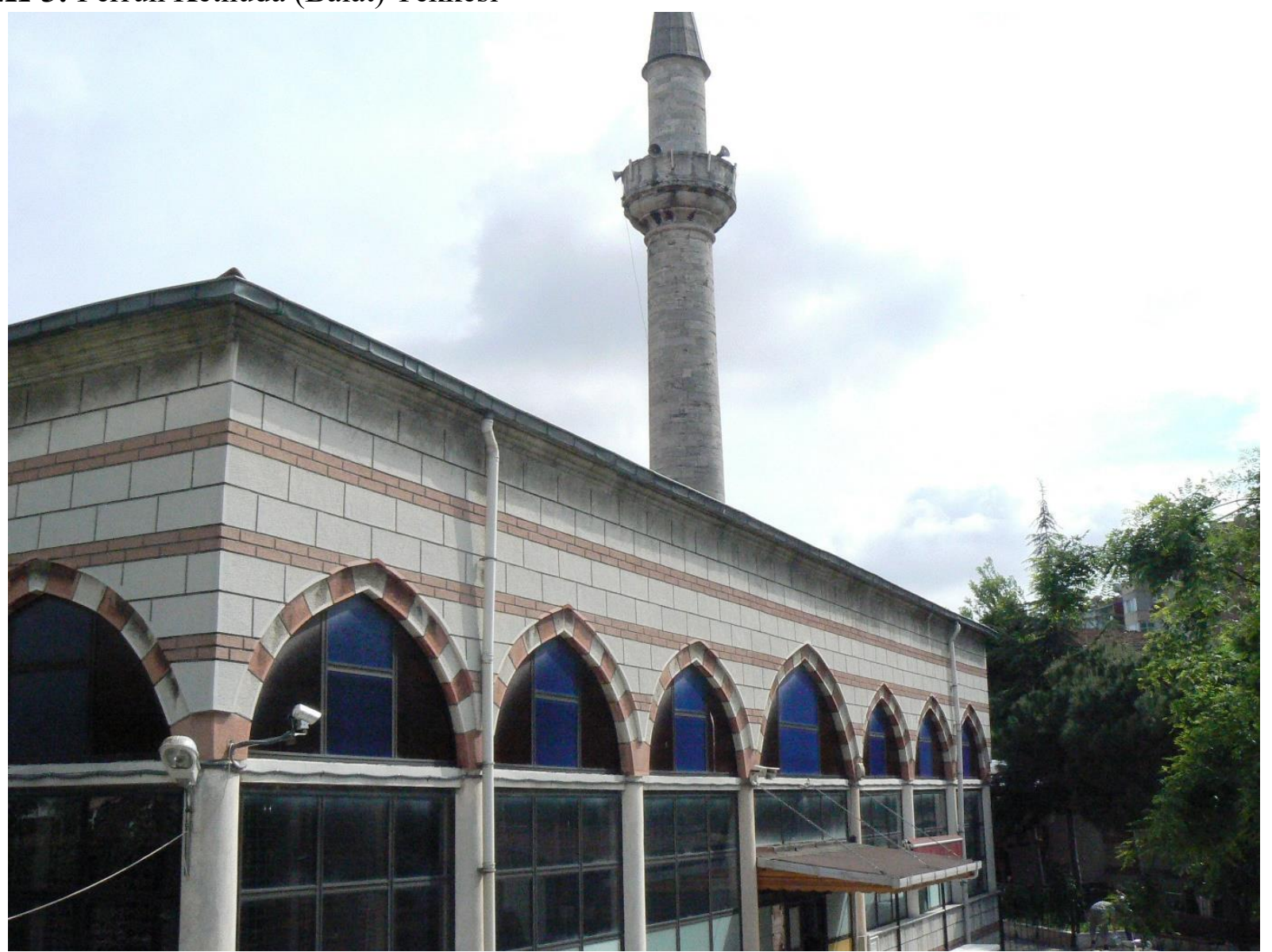

Kaynak: Ayşe Bölükbaşı Fotoğraf Arşivi 
EK-4: Şemsi Ahmet Paşa Camisi ve Türbesi

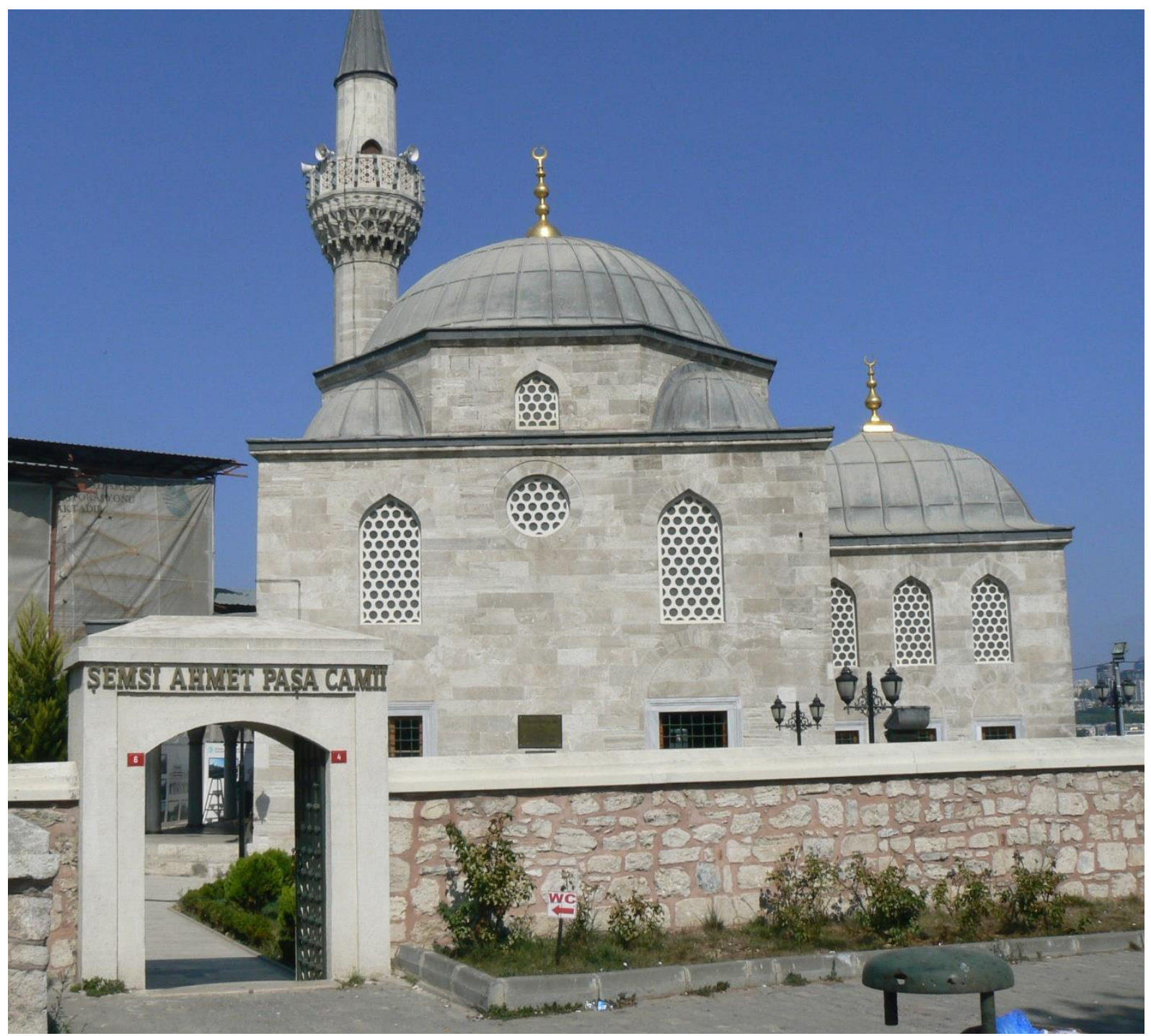

Kaynak: Ayşe Bölükbaşı Arşivi 
EK-5: Şemsi Ahmet Paşa Camisi hariminden türbeye geçiş

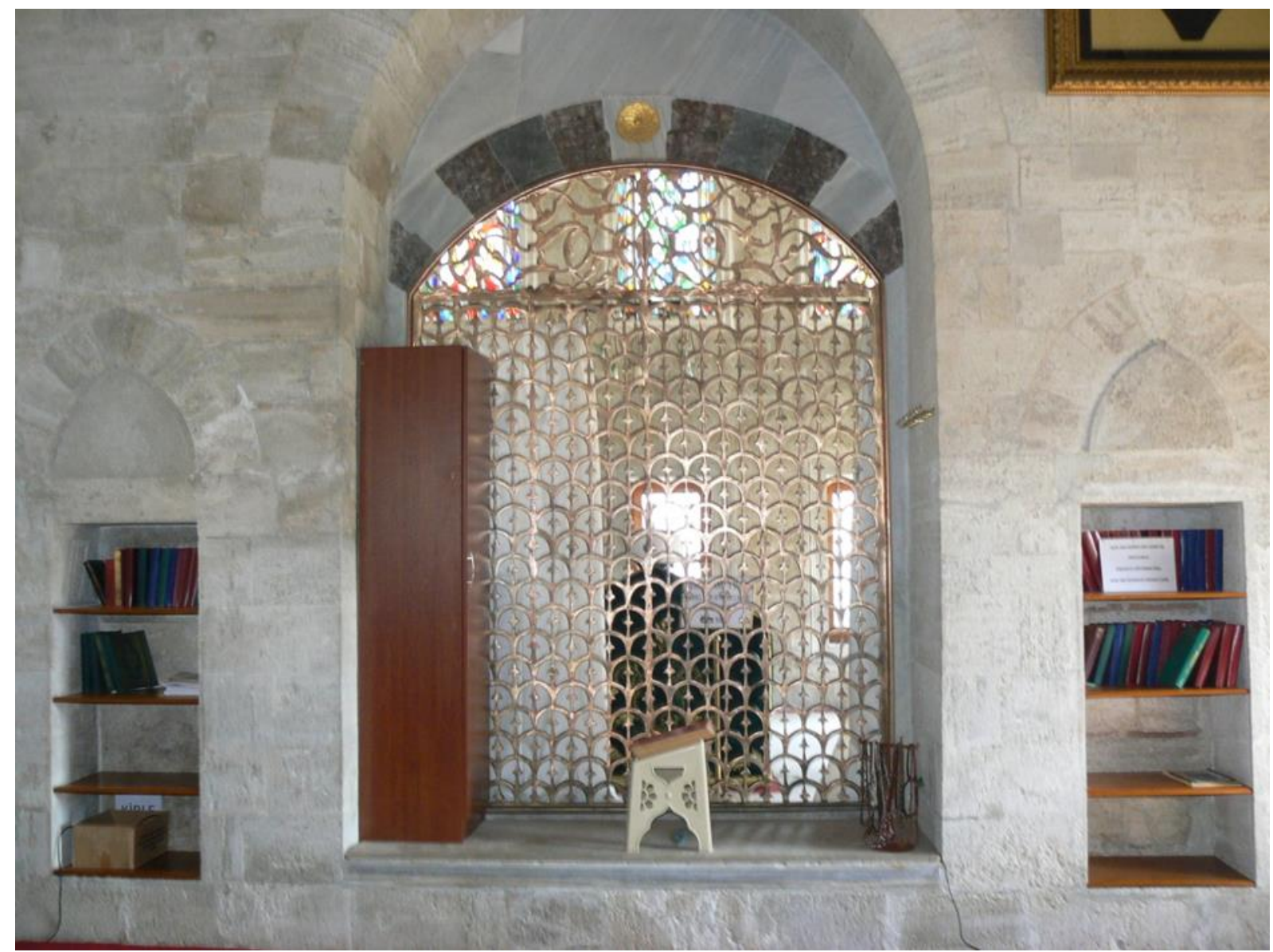

Kaynak: Ayşe Bölükbaşı Arşivi 
EK-6: Şemsi Ahmet Paşa Camisi

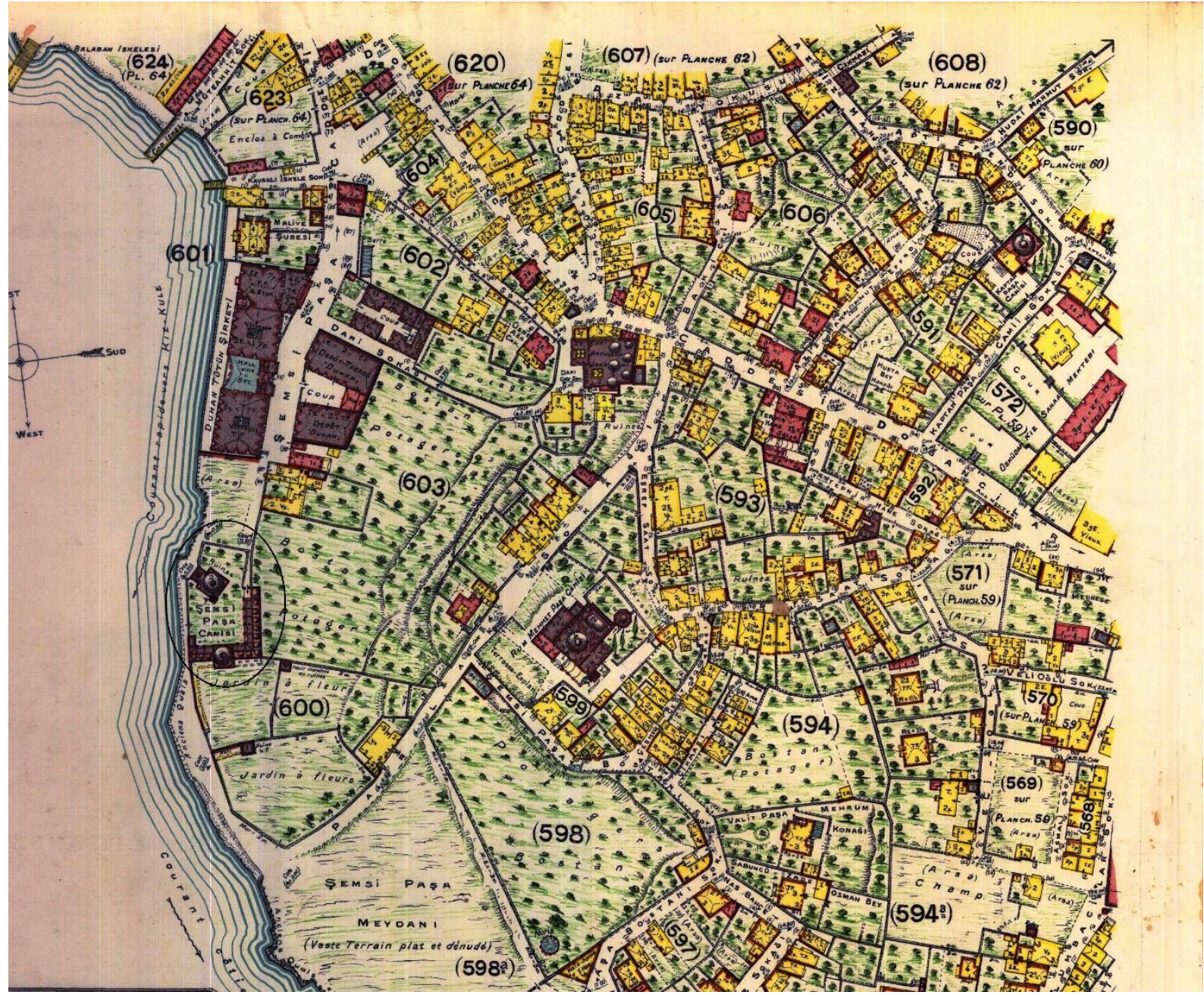

Kaynak: Jacques Pervititch, Sigorta Haritalarinda Istanbul (Istanbul in the Insurance Maps of Jacques Pervititch), İstanbul, 2000 
EK-7: Piyale Paşa Camisi

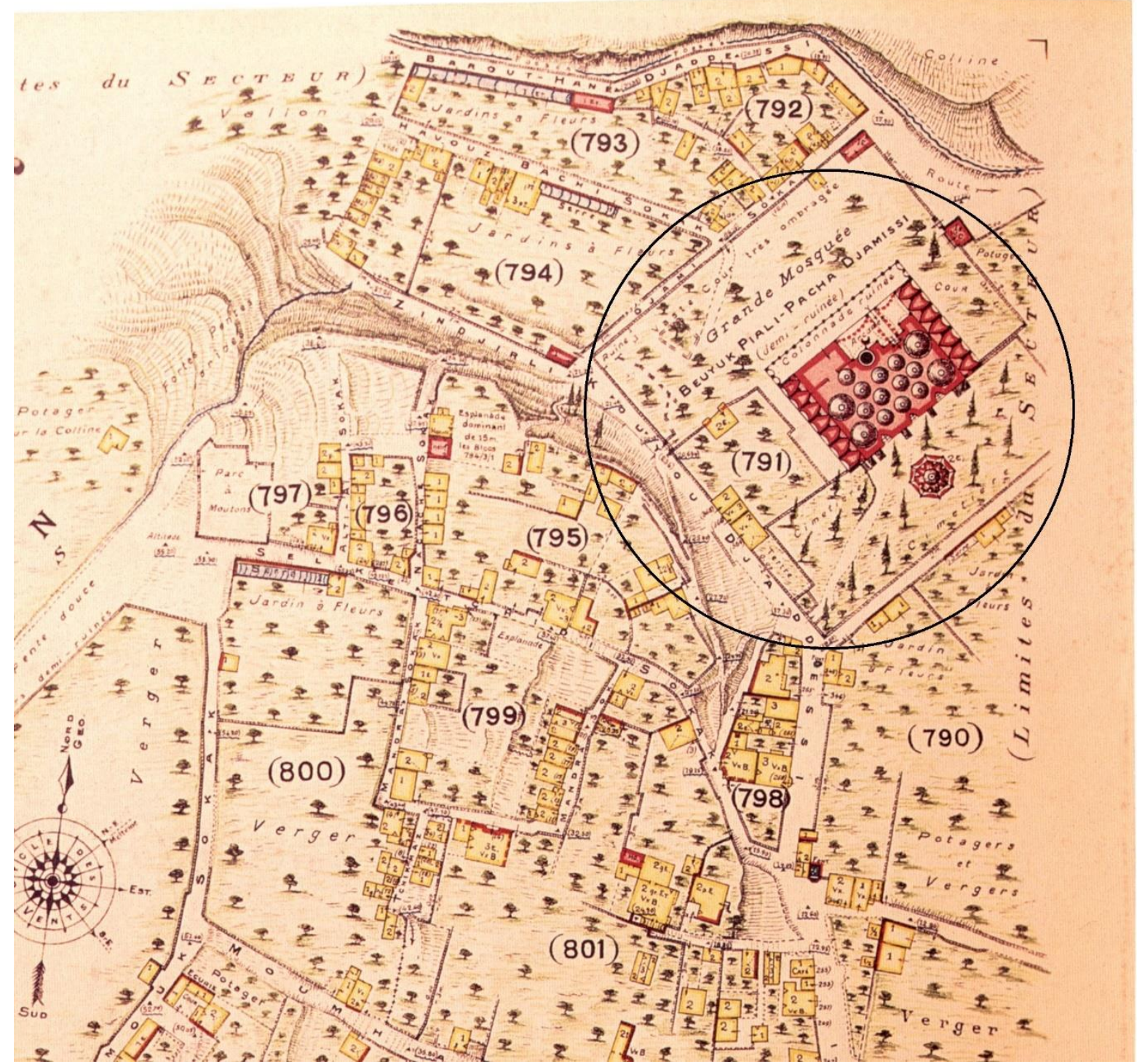

Kaynak: Jacques Pervititch, Sigorta Haritalarinda Istanbul (Istanbul in the Insurance Maps of Jacques Pervititch), İstanbul, 2000 
EK-8: Piyale Paşa Camisi

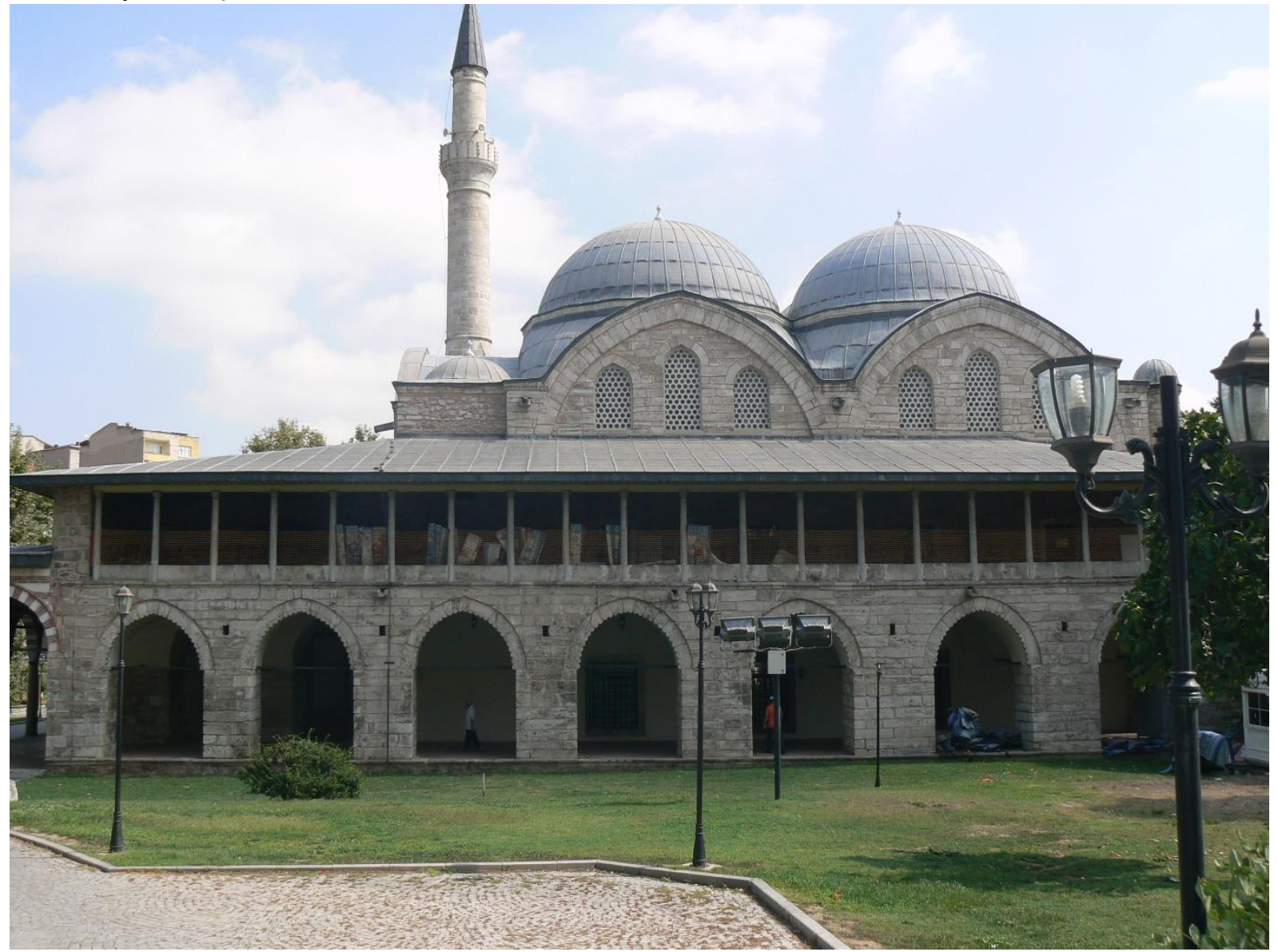

Kaynak: Ayşe Bölükbaşı Fotoğraf Arşivi 
EK-9: Piyale Paşa Tekkesi

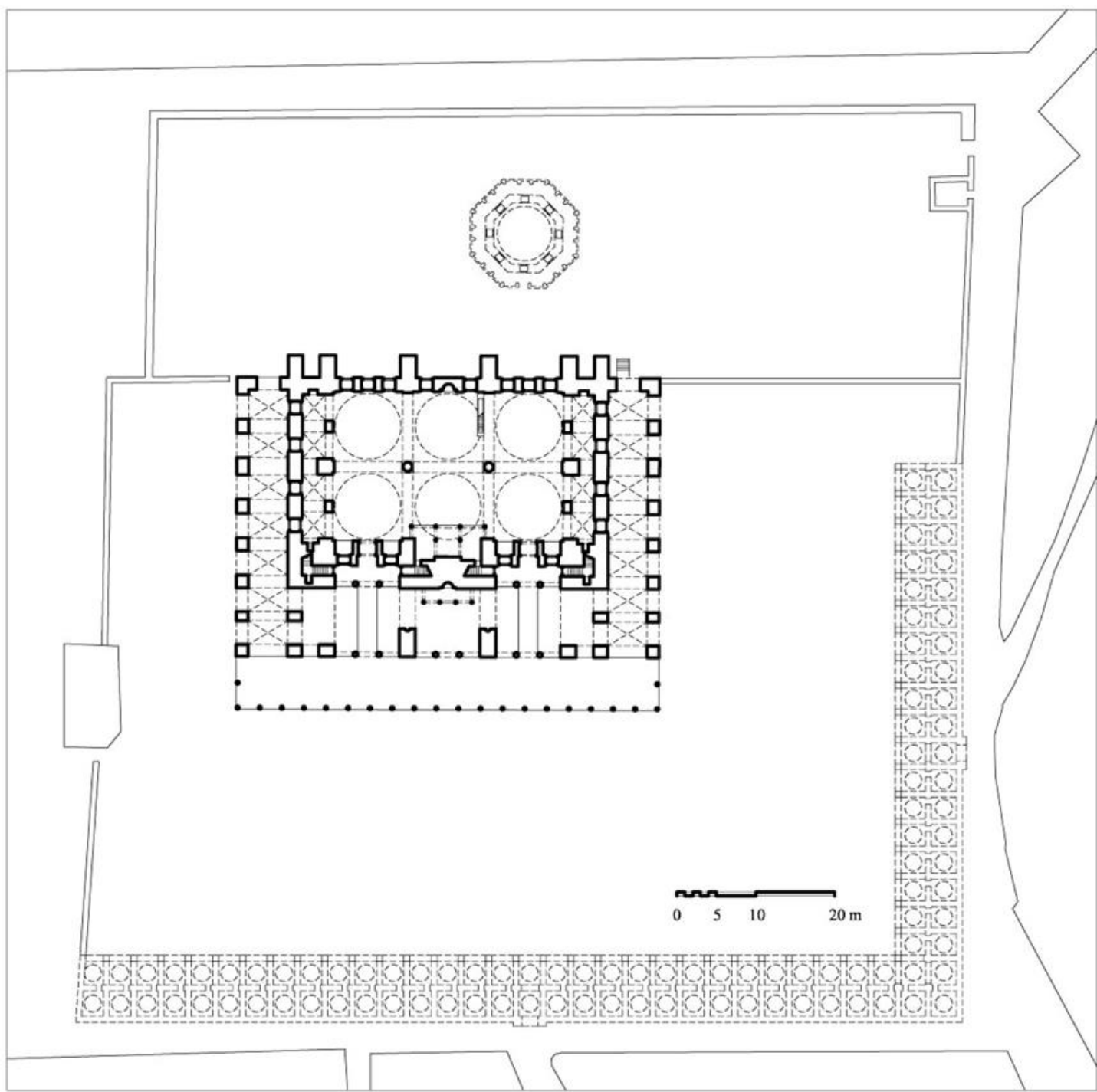

Kaynak: Gülru Necipoğlu, The Age of Sinan - Architectural Culture in The Ottoman Empire, London 2005, s. 423. (Baha Tanman'ın medrese ve derviş hücrelerinin rekonstrüksiyonunu oluşturmasından sonra Arben N. Arapi ve N. Semiz tarafından çizimleri yapılmıştır.) 
EK-10: Şah Sultan Tekkesi'nin cami-tevhidhane binası ile Merkez-zade Şeyh Ahmet Efendi'nin Türbesi

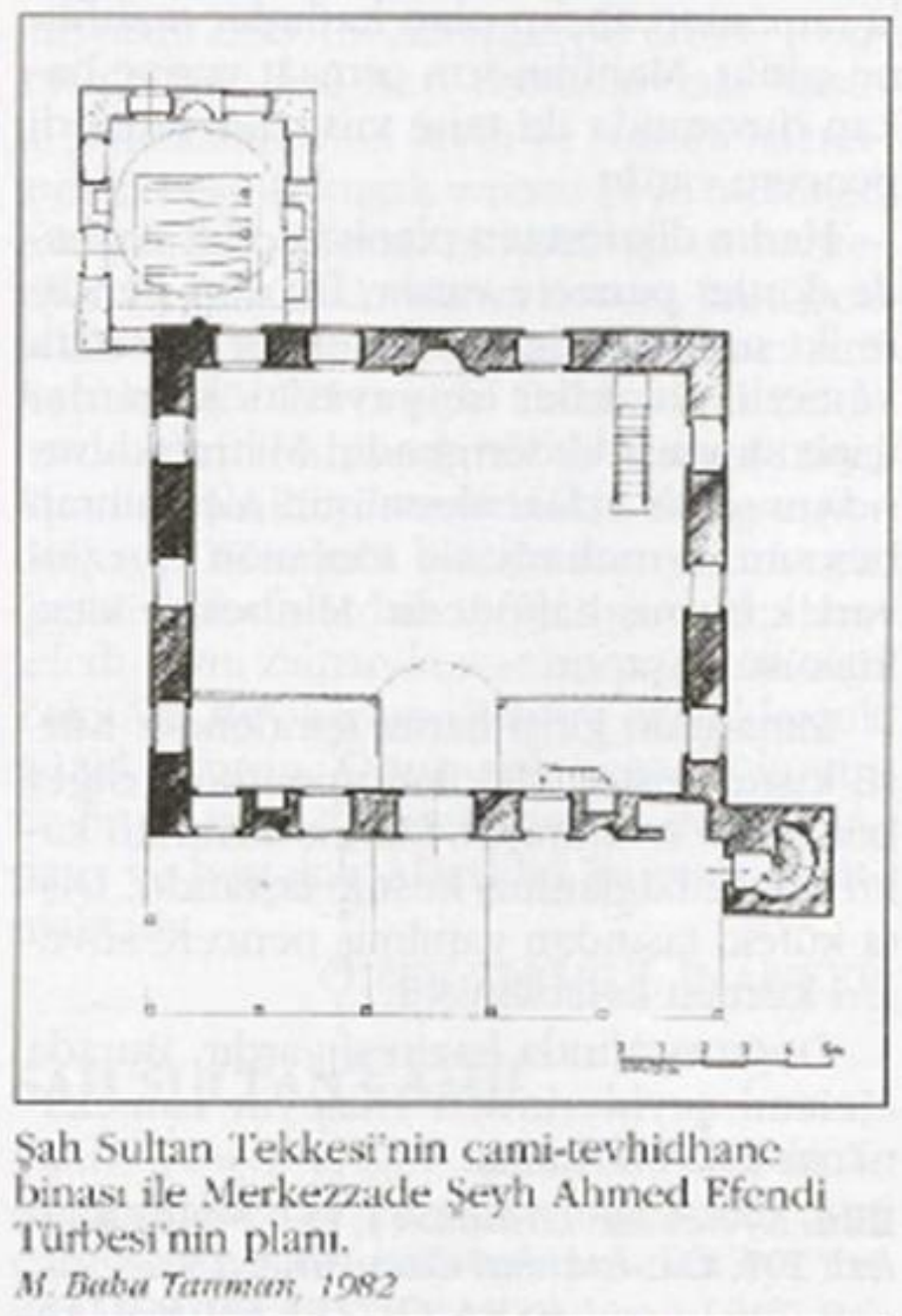

Kaynak: Tanman, M.B., Şah Sultan Camii ve Tekkesi, Dünden Bugüne İstanbul Ansiklopedisi, İstanbul 1994, cilt 7, s. 125-127 
EK-11: Şah Sultan Tekkesi ve yanındaki sarayı (Eyüp)

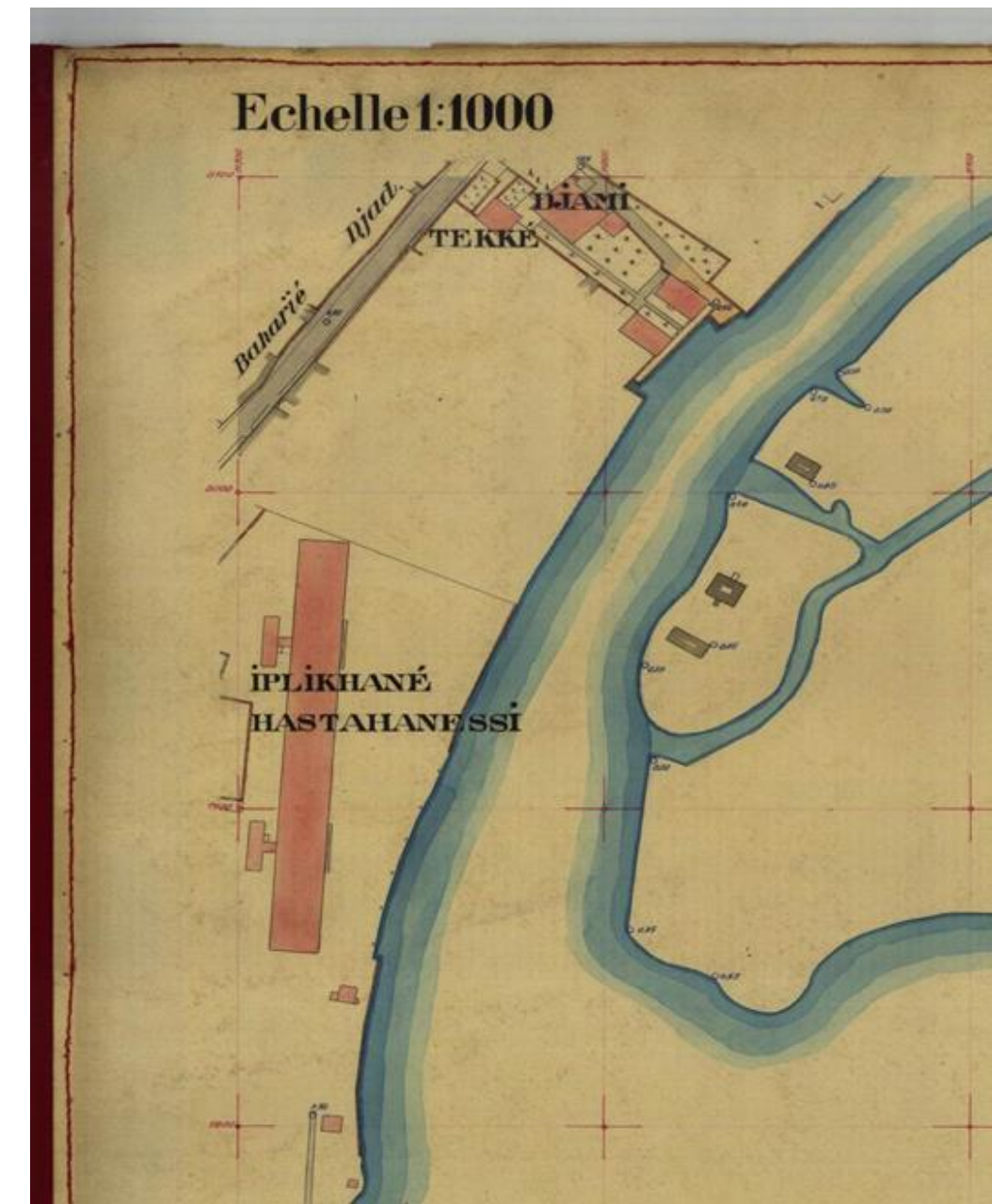

Kaynak: Alman Mavileri: 1913-1914 I. Dünya Savaşı Öncesi İstanbul Haritaları, haz. İ. Dağdelen, A. Mazak, İstanbul, 2006 


\section{EK-12: Şah Sultan Camisi}

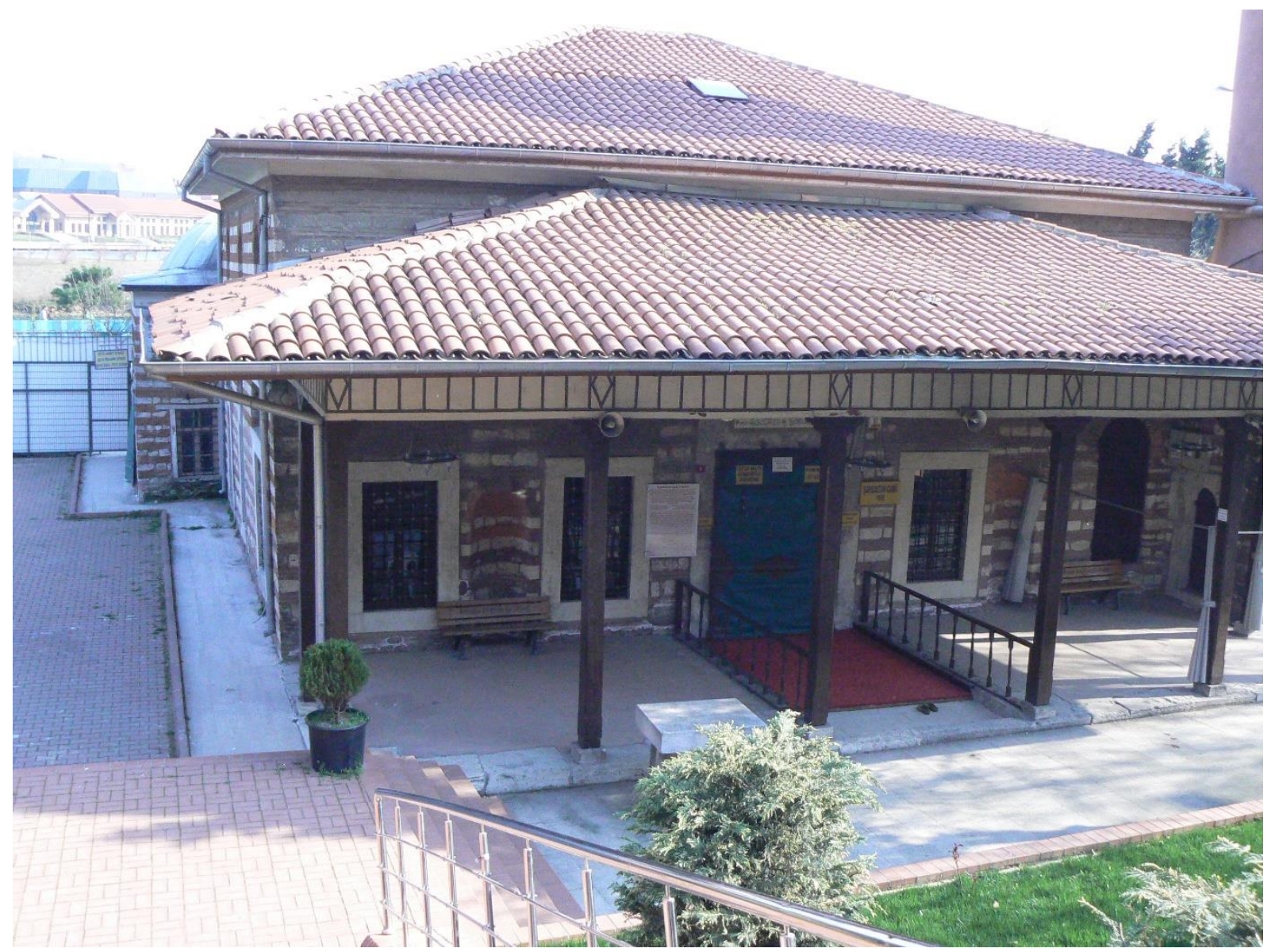

Kaynak: Ayşe Bölükbaşı Fotoğraf Arşivi 